\title{
Liberal peace and peacebuilding: global and local debates in the context of Sri Lanka
}

\author{
Ramya Chamalie Jirasinghe* \\ United States-Sri Lanka Fulbright Commission, Colombo 03, Sri Lanka.
}

\begin{abstract}
This paper examines the key global debates on liberal peace and peacebuilding and their nexus with the Sri Lankan conflict, the efforts to resolve the conflict and the ensuing local discourses. The end of the cold war heralded the possibility of a liberal world order. This triumph of the liberal order underlined a normative assumption of "the end of history", not as a static closure, but as embodying an ideology with the potential for delineating the optimal form of governance for a state, its economy and citizens ${ }^{1}$. Since the end of the cold-war, liberal peace has become the main policy framework that has been used by the International Community (IC) to engage with and intervene in conflict ridden states as a means for creating global peace by stabilising states and strengthening global markets ${ }^{2}$. However, the liberal peace thesis and the attendant liberal peacebuilding interventionist frameworks for local and global peace have spurned a critical discourse that questions the validity of the thesis and the effectiveness of its policy and practice outcomes. Sri Lanka mirrors the global debates and policy impact of the ideological framework of the global thesis, as it has a history of liberal governance (traceable to the $19^{\text {th }}$ century) and liberal peacebuilding (traceable to the $20^{\text {th }}$ century).
\end{abstract}

Keywords: Liberal peace, peacebuilding, state reform, agency, epistemology, war, Sri Lanka.

\section{INTRODUCTION}

This paper aims to provide a sketch of some of the key themes and debates of the contemporary global liberal peacebuilding discourse and their intersection with the discourses on the Sri Lankan conflict and war. It is the objective of this paper to be an initial reference point on critical liberal peacebuilding debates in the global and Sri Lankan discourses for future readers and researchers.
The author maps the global liberal peacebuilding discourses and their intersection with the discourses in Sri Lanka to mirror the epistemological and ontological assumptions derived from the global discourses that have influenced the efforts of resolving the conflict and war in Sri Lanka. This paper summarises a literature review conducted as part of a doctoral research study that critically examined liberal peacebuilding in Sri Lanka from 2009-2015 during and after the military conclusion of the war. The review followed a three-step process (see Levy \& Ellis, 2006: p. 182). The sources used for the review included peer reviewed articles as well as published books. An initial survey identified current key themes and critical debates in the global and local discourses. The Sri Lankan peacebuilding discourse was assessed against the critical global debates on liberal peacebuilding.

The literature on liberal peace and liberal peacebuilding is extensive. It includes classical works, the contemporary academic discourses on them and the vast body of theoretical, empirical, policy and critical literature on contemporary liberal peace and peacebuilding. The body of knowledge on the local scenario consists of literature on the dynamics of liberal peace in Sri Lanka, the conflict in Sri Lanka and the conflict's trajectory and encounter with peacebuilding. This paper will first follow the core thematics of the global literature and the critical debates that surround these themes. It will then assess the key themes and debates in the local body of scholarship. The review will then highlight the existing lacunas in the literature and insights gained from the exploration.

*Corresponding author (ramyachamaliejirasinghe@gmail.com; (iD https://orcid.org/0000-0002-6012-3657) 
Liberalism is an ideology. Contemporary liberal ideology, the philosophical and political roots of which lie in the Enlightenment of $18^{\text {th }}$ century Europe, comprises of several core elements. These are, primarily, independence and equality of sovereign states, and Rule of Law, to which, economic and rights elements have been added over the years (Ikenberry, 2009: p. 73; Russell, 1946) $)^{3}$. The conceptualisation of liberalism, as a framework for peace within a state and as a world order, has roots primarily in the philosophies of John Locke, Immanuel Kant and the Westphalian state system (see Dahl, 2012; Dawson, 1954). Liberal peace has had a substantial normative impact on the motivations, mainly of Western states, as an ideology that could govern local and global state behavior.

Since the end of the cold war, liberal peace has become the main policy framework that has been used by the International Community (IC) ${ }^{4}$ to engage with and intervene in conflict ridden states as a means for creating global peace by stabilising states and strengthening global markets (Chaudoin et al., 2010; Ikenberry, 2009; Mac Ginty, 2011: p. 5; Sabaratnam, 2011: p. 13). The process of this interventionist engagement is termed liberal peacebuilding:

"...defined as those actions undertaken by international or national actors to institutionalize peace, understood as the absence of armed conflict ("negative peace") and a modicum of participatory politics (as a component of "positive peace") that can be sustained in the absence of an "international peace operation" (Call \& Cousens, 2007: p. 2).

However, in the years since the end of the cold war, the record of the ultimate success of this hegemonic liberal peace project has not lived up to its initial triumph and expectations (see Barnett, 2006; Call \& Cousens, 2007: p. 3; Paris, 1997; Paris, 2011: p. 31). The continuing failure of liberal peacebuilding mechanism to resolve the conflict in Sri Lanka is a case in point. The Sri Lankan experience highlights the need for researchers to critically asses the limitations of the normative liberal peacebuilding global discourses that have governed theory and practice. Empirical evidence suggests that peacebuilding is still shaky. Particularly, the ultimate efficacy of international peacebuilding efforts (Call \& Cousens, 2007: p. 6). Call \& Cousens (2007: p. 3) confirm the inherent failings of international peacebuilding and the weaknesses of the fundamental premises on which peacebuilding is grounded. Richmond (2008: p. 4) points out that while there has been a decrease in the number of inter-state conflicts and negotiated peace settlements have increased in the past decade, that much of this apparent success is based on studies done using quantitative methodologies, which fail to capture the dissonance in the local experience of peace. Up to one third to half of terminated conflicts relapse into war within five years (Fortna, 2004: p. 272; Peacebuilding Initiative, 2014). Call \& Cousens (2007: p. 1) note, referencing Licklider, that civil wars that ended through outright victory recurred $15 \%$ of the time, while those that ended differently recurred $50 \%$ of the time. Risk factors such as the number of warring parties, the hostility of the neighbourhood and whether the war in question was secessionist, correlated to the failed peacebuilding attempt (Call \& Cousens, 2007: p. 4; Doyle \& Sambanis, 2000).

The initial triumph of the liberal global order over liberal peace as a possible global framework has therefore, been contested by the ensuing outcomes of peacebuilding. The outcomes have brought into question the hegemonic nature of the Global North's interventionist agenda and the universal validity of the liberal thesis, and have given rise to a critical discourse. Against this backdrop, the Sri Lankan experience is a useful study of peacebuilding attempts to end the conflict, and end the war between the government of Sri Lanka and the Liberation Tigers of Tamil Eelam (LTTE), which finally ended through a military engagement in 2009.

\section{KEY THEMES AND DEBATES IN THE GLOBAL LITERATURE}

The main contemporary global debates center on the applicability of the liberal thesis to states with historical and cultural settings different to that of the European home of the liberal thesis. Concepts of secularism, democratic peace, agency and even citizenship, are currently being reviewed against the original conceptualisations and their inherent assumptions. These debates provide a useful perspective to the exploration of the chronological growth and entrenchment of liberal peacebuilding in the post-cold war global order.

\section{The classical and modern dialogue}

Classical liberal political writings, which emerge from the work of the $17^{\text {th }}$ to $19^{\text {th }}$ century European philosophers, can be separated from that of the contemporary, or new, liberal peace literature of the $20^{\text {th }}$ century (for the new discourses see Doyle, 1983; Min Kim \& Rousseau, 2005; Paris, 2006; Ikenberry, 2009). The literature on liberal peacebuilding and post-war liberal peacebuilding are subsets within the body of contemporary liberal peace literature. However, there is an ongoing dialogue between the classical writings and the contemporary literature.

Classical liberal peace, which emerged from the socio-political backdrop of Europe of the $16^{\text {th }}, 17^{\text {th }}$ and $18^{\text {th }}$ centuries, is a philosophical attempt to develop political means to protect the rights of the individual and 
safeguard private property against the powers of state authority (Russell, 1946; Richmond, 2006). The writings of Thomas Hobbes, John Locke and Immanuel Kant developed the early concepts of individual liberty in relation to the state. They debated the issues surrounding the establishment of just governments that could protect individuals from the "state of nature", as well as from the tyranny of the absolute power of the state (Paris, 2006). Paris (2006: p. 425) identifies a fundamental difference in the concerns between the classicals and contemporaries, which is the different emphasis the classicals lay on the importance of state building and strengthening state institutions as opposed to the contemporaries who take the state for granted.

\section{The debate on secularism}

Locke has been identified as one of the primary thinkers of the $17^{\text {th }}$ century who set the foundation for liberal ideology, a secular society with the separation of powers, through his writings, mainly, Two Treatise on Government (1690).

The current academic literature questions whether Locke's work forms the foundation to liberal secularism, or whether it stemmed from Protestant political theology (De Roover \& Balagangadhara, 2008). De Roover \& Balagangadhara (2008: p. 523) point out that these two sides of the debate on Locke are both valid. The debate has important consequences on the assumptions of the universal validity of liberal ideology. As De Roover \& Balagangadhara (2008: p. 524) point out, Locke's theory of liberal toleration is a secularisation of a theological model. Enlightenment-led liberal ideas stem from a response to the rise of a positivist scientific worldview and the need to situate the individual in this changing socio-political setting.

The current debate questions whether a liberal Lockean theory derived from a Christian theology of liberty and the separation of two spheres (the State and the Church) can be isolated from its theological basis, and whether it is possible to derive principles that can be used for secular legislative purposes in socio-cultural settings different to its place of birth. Some academics (Tuckness, 2002) argue that this is possible, pointing out that the Lockean principles of toleration and human fallibility were used by the founding fathers of the United States such as Thomas Jefferson and James Madison to separate Church and State, as incorporated in the US constitution.

Liberal idealism had three main strands that would resonate throughout the genealogical history of liberal thought, based on the liberal peace thesis of the classical liberals. These were Locke's individualism, Benthem's utilitarianism and Adam Smith's free trade and pacifism. In addition, the core liberal assumptions that would govern liberal peace are universal rationality and individual liberty. The classical liberals' ideally governed state had individual liberty and the protection of private property as its foundation and primary aim (Russell, 1946). Peace was understood as a natural result of the protection of individual liberty and the balancing of the role of the state in creating the ideal environment for individual liberty. These in turn are expected to result in harmony in the domestic sphere which would filter up to the international order (Archibugi, 1995: p. 430; Doyle, 1983: p. 325).

In the historical progression of liberal peace, LaissezFaire, enabled the foundation of the utilitarianism of Jeremy Bentham, which formed the basis for the English welfare state and the liberalism of the last phase of the British empire. Yet, Laissez-Faire was also developed by economists into an argument for free markets in the $20^{\text {th }}$ and $21^{\text {st }}$ centuries. The ability of Adam Smith's work to be the basis for the creation of welfarism with concepts of human goodness at one end, and a faceless, heartless, market system at the other end, speaks of the manner in which Smith's ideas have become secularised overtime (Viner, 1960). Laissez-Faire's contemporary face is neoliberalism, which has proved to be weak at enabling an equitable peace (Richmond, 2015: p. 449). Yet, in the modern world, liberal ideals that the classical moralpolitical philosophy have generated are constituted by the International Community to be the logical framework for global peace. This proposition has come into the modern discourse primarily as the democratic peace thesis and has been the basis for the entrenchment of human rights into the liberal international system (Richmond, 2008: p. 90). The concepts of democratic peace and the free markets are core strands in the contemporary liberal peacebuilding policy framework.

Several key $20^{\text {th }}$ century academic works have built on the work of the classicals. The liberal peace thesis and its evolution into the modern liberal peacebuilding project will not take the dimensions that it does, without the work of academics such as Rawls, Lederach and Galtung. Of significant importance in the literature of the early contemporary liberal peace project is John Rawls' Theory of Justice (1971), followed later by his Law of Peoples (1999), where Rawls offers the possibility of using a concept of justice as fairness in a society and later expands it to include a concept of justice between societies that forms the grounds for a liberal foreign policy of states (Beitz, 2000; Doyle, 2006: p. 110; Recchia, 2009: p. 167). 
The trend of secularisation of classical liberal work reaches its epitome in contemporary academic work in the effort to make secularism a-theoretical, as well as to separate contemporary liberal peace from its Enlightenment heritage (Fortier, 2010: p. 1004). As Dryzek, Honig \& Philips point out (in Fortier, 2010), the enlightenment liberals were successful in developing a philosophy that responded to the needs of their time. In the case of the contemporary liberals, they have been unable to respond to the multiculturalism and globalisation of the present context. As De Roover et al. (2011: pp. 571-599) point out with regard to the Indian case of secularism,

"secularization of western political thought has not produced independent rational principles, but transformed theological ideas into the "topoi" of a culture".

\section{Democratic peace and core values of liberal internationalism}

For the classical liberals, international peace depended on local peace (Polat, 2010: p. 326). Many practitioners have translated this and evolved this classical concept as a means to the prevention of outbreak of violence through governance and state building (Radin, 2012). In the early $20^{\text {th }}$ century, concepts of liberal peace were brought in as a platform for creating a global order. In this phase of the early $20^{\text {th }}$ century, the ideals of Woordrow Wilson, Alfred Zimmern, Norman Agnell and James T. Shotwell transcribed liberal concepts into a global ideology for peace against the backdrop of the devastation of the World War I (Ghosh, 2011: p. 20). It is with Kant that the possibility of liberal peace succeeding at a worldwide scale was first considered, and thereby, a possibility of international relations between nations based on a particular ideology was first floated (Franke, 1995: p. 280). It was in Kant's writing in To Perpetual Peace. A Philosophical Project, that the much contested, but the now almost entrenched International Relations (IR) theory of democratic peace was born. It assumes that democracies do not wage war on each other and introduces the concept of cosmopolitan law to connect the domestic to the global (Doyle, 1983: p. 325; Archibugi, 1995: p. 430).

The contemporary focus of the democratic peace thesis has fallen on, "Open markets, international institutions, cooperative security, democratic community, progressive change, collective problem solving, shared sovereignty, the rule of law", in some variant or other (Ikenberry, 2009: p. 71). Whatever the focus, liberal peace now has at its core, the dimensions of sovereign independence and equality of states, Rule of Law and in addition, at times, economic and rights dimensions (Ikenberry, 2009: p. 73).

\section{The liberal thesis and the colonial self}

While concepts of the state, citizen and the international order solidified from the $16^{\text {th }}$ to the $18^{\text {th }}$ century in Europe and the U.S., the repercussions of Europe's transformations had a different impact on its colonised people (Nandy, 1983). With the entry of the colonisers into pre-modern states such as India and Sri Lanka in the $16^{\text {th }}$ century, the material and spiritual spheres of those societies, which had previously been in one sphere, had to separate to re-create forms of resistance and national consciousness (see Chatterjee, 2014). Instead of the cataclysmic inversion of the individual's relationship with the divine and the state that took place in Europe, in the colonies, the relationship of the individual to the divine and the state was severed into two spheres. For their material benefit and survival, citizens would have adhered to the material and ideological state of the colonisers. However, they would have become highly skilled at subverting the state in their private spiritual existence (see Chatterjee, 2014: p. 31; Nandy, 2014). The colonial culture managed dissent through socioeconomic and psychological rewards and punishments, which always led to the colonised resisting the coloniser by psychological means (Nandy, 2014: p. 3).

According to Mehta (1999: p.1), the liberalism of British thinkers and administrators in the $19^{\text {th }}$ century could not be transported to the Empire and embedded without contradictions in an "unfamiliar" context. Mehta says,

"By unfamiliarity; I mean not sharing in the various ways of being and feeling that shape experience and give meaning to the communities and the individuals who constitute them, in a word, not being familiar with what was experientially familiar to others in the empire" (Mehta, 1999: p. 2).

Further, Mehta (1999) has pointed out, the liberalism and empire were a contradictory and problematic relationship. Such contradictions were bound to permeate, for instance, in Sri Lanka, with the Colebrooke-Cameron reforms.

Of centrality to the liberal peace thesis is the role of the citizen and his/her agency. This concept, which has evolved from the European Enlightenment, assumes a particular type of citizen and his/her ability to engage with the state and define its form, using his/her agency (see Migdal, 2001; Oslon, 2008: p. 40). The current debates on the concept of the citizen and various theoretical basis of the definition of "citizen" attempt to 
expand the notion of "citizen" from a mere construction of the state to a more nuanced subject that is constrained by circumstances and structures as much as it is a space capable of "development" and "an orchestrated achievement" (Oslon, 2008: p. 41). Oslon (2008: p. 43) argues that it is essential to be able to have a nuanced exploration of the citizens' limits for potential, taking into account that the very concept of citizen has historic, cultural and hegemonic specificities. In the introduction to their special volume on "citizenship", Lazar \& Nuijten (2013) argue that:

"citizenship might be either an analytical category denoting political agency generally even where not specifically and explicitly articulated around questions of citizenship, or a language of the political that may or may not be used by local actors" (Lazar \& Nuijten, 2013: pp. 3-4).

\section{The emergence of liberal peacebuilding}

The modern concept of "building" peace, as in peace being a norm or state that could be constructed, emerges from Johan Galtung's work on the structural nature of violence, peace and avenues for peace research (Galtung, 1969). Galtung points out that peace could exist in a positive or negative state. In defining the concept of negative peace he introduced the idea of structural violence, summed up as social injustice (Galtung, 1969, p. 171). In his seminal work of 1976, Galtung used the phrases "Peacekeeping", "Peacebuilding" and "Peacemaking", all of which would create the intellectual catalyst of the modern academic and policy framework for an interventionist approach to creating liberal peace in conflict affected states.

Many researchers would build on Galtung's seminal work and the most important contribution possibly came in the first two decades following Galtung's conceptualisation by John Paul Lederach, a sociologist. In his work on conflict resolution in South America, Lederach had noted the role of mediation in the peace processes and identified that this process needed to be examined as "process", "structure" and "context" (Wehr \& Ledereach, 1991: p. 85). It is Lederach who identified the importance of the cultural background to a conflict and enlarged the field of peacebuilding to include a concept of transformation that takes place over a long timeframe, where two variables; the balance of power and conflicting interests and needs, play the key roles (Glaser, 1997).

\section{Post cold war liberal peacebuilding}

The end of the cold war was the defining moment in the chronological progress of peacebuilding as a policy agenda of the liberal global order (Sabaratnam, 2011: pp. 13-27). Peacebuilding is

"...defined as those actions undertaken by international or national actors to institutionalize peace, understood as the absence of armed conflict ("negative peace") and a modicum of participatory politics (as a component of "positive peace") that can be sustained in the absence of an international peace operation" (Call \& Cousens, 2007: p. 2).

The euphoria of the end of the cold war was picked up by the United Nations (UN) and culminated in the Secretary General, Boutros Boutros-Ghali's An Agenda for Peace (United Nations, 1992). In this Agenda, Boutros-Ghali emphasised that the UN saw the then world political climate as an opportunity for the UN to achieve the objectives of its Charter and the opportunity to transform itself into an agency that could create world peace and security (UN, 1992). The policy documents enabled the transformation of the ideology of liberal peacebuilding into an institutionalised policy framework. The UN pioneered the movement of liberal peacebuilding theory into policy.

The documents that followed the Agenda for Peace, The Supplement, The Agenda for Development and The Agenda for Democratisation, built on the concepts and honed in on democratisation as the key element that would bind nations in peace. As Russet (1997: p. 496) points out, while Boutros-Ghali's envisioning of this post cold war liberal world order is not in precise focus, the picture is in place. Using his position as the head of the UN, Boutros-Ghali speaks from the "bully-pulpit" (Russet, 1997: p. 496) and sets the tone and the emphasis for peacebuilding in the years to follow. Sabaratnam (2011) points out that this new UN initiative would go on to change the landscape of foreign policy thought. Yet, as Richmond (2007: p. 249) points out, more than two decades later, they are yet to be fully integrated in a cohesive manner. As sub-state conflicts increased and the concept of failed states emerged in the 1990s, the focus on building states through liberal tools was underlined by the need for socio-economic strengthening of these societies. Lipset (1959: p. 71) for instance, had already identified the correlation between economic prosperity and legitimacy if a democratic peace was to succeed in a state. Liberal peacebuilding added on the development mantel to its tool box.

The discourse on the correlation between peace and inequality was enlarged into the debate between democracy and development. A discourse of "illness" which needed curing entered the liberal peacebuilding 
framework (Kraxberger, 2007: p. 1055). The early language of the narration of failed states was rife with images of a liberal hegemony that identified the chaos of the "other". The narrative noted the failed states' complete incapacity to sustain themselves, their economic deprivation and their rampant chaos with collapsing governments. According to the narrative, these failures result in rampant abuse of human rights, imperiled citizens and neighborhoods in crisis with refugee inflows and threats to security (Helman \& Ratner, 1992-1993: p. 3). As Duffield (2007: pp. 228-229) notes, the post cold war dichotomy stemmed from liberalism's enlightenment heritage which equated culture with government.

The IISS database notes 51 active conflicts around the globe in February 2014 (IISS, 2014). From 19482013, the $\mathrm{UN}^{5}$, has had 69 peacekeeping missions worldwide, with over 50 of the missions originating after 1990 (UN, 2014). Duffield (2007: p. 236) has argued that the concept of humanitarianism has enabled the West to re-expand its frontier in the post cold war era, based on the inability of states to protect its citizens and improve their lives, which in turn prompts the threat of circulation of populations and gives a justification for intervention.

\section{Post-conflict peacebuilding}

Peacebuilding after the end of a military conflict is captured by the term "post-conflict peacebuilding" (see Tom, 2011 for a discussion on the term). The term has no clear definition. However, the presence of elements and achievement of certain milestones are used as the most feasible means by which to evaluate whether a post conflict context has been achieved in a state. These include cessation of direct military activities, signing of peace accords, attempts to reform the state, development activities and the collapse of the faction associated with military conflict (Call, 2008; Brown et al., 2008: p. 4).

Post-conflict liberal peacebuilding literature is dominated by the narrative on state building through state reform (Richmond \& Franks, 2009; Call \& Cousens, 2007). The debate on post-conflict peacebuilding has expanded into the moral issues of obligations of the international community against the backdrop of national sovereignty. It has, in turn, also spawned accusations of neo-colonialism. However, there is no systematic, normative theory of post-conflict peacebuilding (Gheciu \& Welsh, 2009).

In their detailed work on the ethics and justification of post-conflict peacebuilding, Gheciu \& Welsh (2009) have identified three main contexts of the ethical debate of post-conflict peacebuilding, which are: 1 . The debate on the content of jus post bellum; 2. On the literature on trusteeship and international administration; 3. The literature on IC's responsibility to rebuild. The following section explores some of the key debates in post conflict peacebuilding.

\section{The concept of jus post bellum}

The concept of jus post bellum (justice after war) is an extension of the concepts of jus ad bellum (right to war) and jus in bello (justice in war), which centre around the morality of war. The central thesis of the just war tradition is whether the war was morally justified and whether it was fought justly, which imposes a moral obligation on the aggressor to fight and go to war in justifiable ways. Jus post bellum is an extension of this principle which imposes the same moral expectation on the victor, where the victor is expected to bring about the outcomes that justified going to and being at war.

The jus post bellum concept can be broadly defined within a minimalist framework where the post conflict engagement is considered in terms of restraint by the victor. On the other hand, the maximalists such as Walzer and Orend, hold the position in terms of responsibilities (Bellamy, 2008: p. 602). The minimalist position of status quo ante would only be a return to the setting that had the seeds of conflict in the first place, while the maximalist position enlarges its remit to accountability and justice through war crimes trials (Bellamy, 2008). A formal accounting of the past crimes in the aftermath of war is now the norm in post conflict peacebuilding. Mechanisms such as criminal trials or historical commissions are considered essential for post-conflict reconciliation (Mendeloff, 2004: p. 355; Freidman, 2015). The aim of war-crimes trials, says Bellamy (2008: pp. 612-625), should be to prevent revenge while ensuring a combination of retribution and rehabilitation which can lead to reconciliation. Both the minimalist and maximalist positions open up tensions (Bellamy, 2008). However, Mendeloff (2004: pp. 375-376) argues that justification for truth telling mechanisms are based on both factual and theoretical assumptions that are contested and dubious.

In effect, both justice after war and justice in peace have no defined normative frameworks. Bellamy (2008: pp. 623-624) points out that, the debate needs to take into account the following: that justice of peace should be evaluated separated from whether the war was entered into and fought justly, accepting the differences between the vanquished's "entitlements" and the victor's "obligations". Bellamy (2008) further develops this thesis to emphasise that

"in the longer term, it is important to interrogate the questions of where the authority to define the peace lies and the impact of post bellum judgments 
on ad bellum and in bello considerations" (Bellamy, 2008: p. 625).

However, the maximalist approach has had stronger resonance in the post-conflict peacebuilding framework. Bass (2004: p. 403), for instance, argues that in reconstruction of a post-conflict state (primarily, political and economic), the agent need not be neutral. Instead, he argues the agent should seek to give victims solace and rope in the aggressor, should attempt to include as many stakeholders as possible and that the ultimate aim should not be the creation of a perfect state, but a non-genocidal one. It is in relation to this normative framework of $j u s$ in bello that war-crimes trials have been considered essential in the jus post bellum situation. The process is one of stripping the veneer of position and title from the person and exposing and reinstating that ultimately crimes are committed by individuals and that they need to be brought to justice for their crimes (Bass, 2004: pp. 404-406). Yet, as Bass (2004: p. 405) points out, in postwar situations, there is an excruciating trade-off between the importance of peace outweighing the urgency for justice.

\section{Sovereignty vs. responsibility}

The IC's eagerness to engage in post-conflict peacebuilding has created tensions between a state's sovereignty and the IC's responsibilities. The democratic peace theory contends that democratic states are unlikely to wage war against each other (Rosato, 2003; Ferejohn \& Rosenbluth, 2008) and the Westphalian global system is entrenched in the concept of state sovereignty, equality and non-intervention. The issue of human security deals with the need to protect the individual in society (Barnett, 2009). The concepts together have formed the current thematic contradictions of the liberal peacebuilding project (see Kapitan, 2006; Lynch, 2002). One promotes democratisation (manifesting in the push for early elections in post war states), safeguarding of the rule of law and marketisation in peace building projects in a sovereign state system. The other concept has evolved to promote intervention for human security over the state's right to sovereignty (Doyle, 1992; Zakaria, 1997; Paris, 2001; 2002).

The emergence of the concept of 'The Responsibly to Protect (R2P)', developed by former Australian Foreign Minister Gareth Evans and endorsed by the 2005 UN General Assembly, gave the UN and the states promoting the liberal peace project a moral basis for humanitarian intervention at times of crisis (Evans, 2007). The concept of R2P is yet undefined as to its exact parameters and timing of intervention, or as to the role of the $\mathrm{UN}$ and the governance mechanisms for justifying intervention, but there is a consensus that this concept offers a basis on which to protect vulnerable communities (Barnett, 1997; Chandler, 2009; Doyle \& Sambanis, 2007). Gheciu \& Welsh (2009: p. 123) define four principles that drive the IC's logic for engaging in post conflict societies. These are, the IC's recognition of its own material and symbolic power, the projection of democracy as a universal value, the rendering of statesmanship and the desire to restore self-determination (Gheciu \& Welsh, 2009: p. 123).

\section{Scholarship from the global south}

The contribution of scholars from the South to the field of liberal peace study is twofold. Firstly, Southern scholars from multiple disciplines have contributed to the expansion of the boundaries of IR liberal peace scholarship, mainly from disciplines now labeled as postcolonial and subaltern studies. Secondly, scholars working in global politics in the South have explored the concepts in terms of local specificity and experience and have contributed empirical data to Northern scholarship. However, the division of knowledge into two bodies, as that emerging from the center and that from the periphery, is in itself problematic as it proclaims the marginality of some knowledge over the acceptance of the rest as mainstream and valid. As Khoo (2013), referring to Connell points out, even critical and "respectful" studies of the South tend to take the global construction of the social for granted and uses the South as a source of data for "...filling in thought categories created by metropolitan intellectuals" (Khoo, 2013).

Nevertheless, a significant group of scholars (both in global politics and in other disciplines) from the South have contributed to the theory of liberal peace in addition to making significant empirical contributions. Theoretical contributions have come from Ashish Nandy (2014), Urmila Phadnis (in Phadnis \& Ganguly, 2001), Aijaz Ahmed (1994) and Partha Chatterjee (2014). Scholars from East Asia have attempted to create Asia-centric theories that account for the specific issues of the region that are anomalous of the existing liberal peace assumptions. The work of East Asian scholars such as Beng-Huat (1994; 2000), Lam Peng Er (Lam, $1999 ; 2012 ; 2015)$ and Mutalib (2000) have explored the specificity of the Singaporean democratic experience, which, despite its high level of development in South East Asia, remains a centralised, quasi democracy (Kadir, 2004: pp. 324-325). Lam Peng Er's contribution has been significant with a substantial body of work on East Asian, especially among others, Japanese and Singaporean aspects and specificity on democracy, peace diplomacy and liberal principles (Lam, 2015; 2012). Scholars such as Beng-Huat (2000) have explored the phenomenon of re-indigenisation and the possible reversing of hybridity. 
Also of significance is the work of Hideaki Shinoda, of the Graduate School of Global Studies, Tokyo University of Foreign Studies, who has made a substantial contribution to the mainstream debates on liberal peace themes such as the concept of state sovereignty, constitutionalism, the right to intervention and the right to resistance (Shinoda, 1998; 2000; 2001). Shinoda's work on liberal peace has included contributions to the debates on conflict and human security and the rule of law in peace operations (Shinoda, 2003; Shinoda \& Uesugi, 2005).

\section{Empirical data}

While the current debate and critique continues, there has also been an attempt to empirically prove the validity of some of the liberal theories and assumptions (Dafoe, 2011; Doyle \& Sambanis, 2000; Franke, 1995; Lars-Erik, 2001). Scholars have used empirical data to evaluate the role of economic factors in civil war (de Soysa, 2002; Blattman \& Miguel, 2010). Others look at how political regime types and political communities design the parameters for peace after conflict (Chandler, 2007; Kaye \& Beland, 2009; Hamieh \& Mac Ginty, 2010; Bell \& O'Rouke, 2007). Also, the empirical work on peacebuilding have attempted to identify factors that impact on peace such as "Republican representation, an ideological commitment to fundamental human rights, and transnational interdependence" (Doyle, 2005: p. 1). Others have looked at the impact of local factors and stakeholders engaging dynamically with the offered peace instead of being passive recipients of peace as shown in case studies in African countries such as Sierra Leone (Ismail, 2008; Tom, 2011; Roberts, 2011). These attempts have sought to gather empirical data to test the validity of the liberal peace thesis. The basis for this research can be traced to the $20^{\text {th }}$ century "path breaking article" by Wade Huntley in 1996, which reinterprets the work of Immanuel Kant's pacific union as a systemic phenomenon (Harrison, 2010: p. 155).

The prolific impact that the democratic peace thesis has had on the modern IR discourse, and the ensuing research on this thesis, has been analysed by Harrison (2010) to show that democratic peace thesis research has been progressive in terms of Laktos's method of scientific research programmes. Harrison (2010: p. 155) says that since Huntley, this analysis has taken a systemic position. However, while Harrison identifies the various themes and critiques of the democratic peace thesis that have emerged in the research, he concludes that democratic peace research tends to be inductive, hypotheses are derived ad hoc and researchers count too heavily on empirical data without focusing on developing novel theoretical propositions (Harrison, 2010: p. 162).
Of significance to the empirical body of work on liberal peace are the numerous data sets on liberal peace, democracy, conflict and violence that are hosted by peace research institutions and universities. The oldest of these is the Peace Research Institute of Oslo (PRIO), which includes data sets on armed conflict, governance and replication data (PRIO, 2016). Others include, the data sets at the Center for Systemic Peace (2016), the University of Gothenburg, Sweden (2016) and the Global Pathfinder Database of the S. Rajaratnam School of International Studies, Nanyang Technological University, Singapore (RSIS, 2016). The Global Pathfinder Database contains information and data on global terrorism and emerging trends. The University of Gothenburg, Sweden and the University of Notre Dame, collaborated project, Varieties of Democracy (V-Dem, 2016), is an extensive database for conceptualising and measuring democracy in countries. The project distinguishes between seven forms of democracy: "Electoral, Liberal, Participatory, Majoritarian, Consensual, Deliberative and Egalitarian" (V-Dem, 2016).

\section{THE DISCOURSE ON LIBERAL PEACEBUILDING IN SRI LANKA}

The local literature on liberal peace and peacebuilding falls into six categories that originate with the modern Sri Lankan State and parallels the evolution of the global liberal peace and peacebuilding literature. These are:

1. Policy and administrative documents derived from global liberal peace ideology originating in the $19^{\text {th }}$ century: these include colonial reform documents that mirrored, albeit contradictorily and uneasily, the social reforms taking place in Britain through policy changes towards the empire and its colonial subjects. The Colebrooke and Cameron Papers of 1832 and the Morgan Committee Papers of 1865 are examples of primary documents of this category.

2. Policy and administrative documents that use liberal peace mechanisms to consolidate the hegemonic goals of communities: as the structures of the state became formalised along the lines of a liberal peace ideology of power sharing and equity, the polity began to utilise the mechanisms of the state to achieve communal and individual goals for power. Examples of this body of literature in the early modern state range from the documents of Governor Horton in response to Colebrooke-Cameron reforms, to the consolidation of communal and executive power through the constitutions of 1972 and 1977.

3.The historiographical, political,IR andanthropological discourse on the hegemonic contestation between 
communities: this is the body of secondary literature that studied and continues to study the ensuing conflict between communities through the prisms of different academic fields. There is a vast body of work to which historians such as K. M. de Silva, Colvin R. de Silva, Sujit Sivasundaram, Nira Wickremasinghe and Ananda Wickremartne; anthropologists such as Gananath Obeyesekere, H. L. Seneviratne and Stanly J. Thambiah and; political scientists and International Relations scholars such as A. R. Ariyaratne, Neil DeVotta, Rohan Gunaratna, Amal Jayawardane, Dayan Jayatilleka, Gamini Keerawella, Shelton Kodikara, Nayani Melegoda, S. D. Muni, Jane Russell, Jayadeva Uyangoda, Maneesha Wanasinghe-Pasqual and Mahinda Werake, have contributed to, among others. There is also a significant discourse on power sharing by politicians and opinion makers such as S. W. R. D. Bandaranaike, Peter Keuneman, Chanaka Amaratunga and Neelan Tiruchelvam.

4. The discourse of the civil society ${ }^{6}$ and civil society movements: in the 1980s, with a global focus on civil society as a medium for socio-political change (Alagappa, 2004: p. 3), the liberal economic policies and the growing conflict in Sri Lanka enabled local and international non-governmental organisations to emerge in Sri Lanka. In the succeeding decades, civil society has been appropriated into the dominant ideological discourse of the time. Much of the civil society discourse of the present time is set within a liberal peace framework, such as seen in the work of the National Peace Council (NPC), Center for Policy Alternatives (CPA) and International Center for Ethnic Studies (ICES). Fernando (2014) identifies that NGOled civil action in Sri Lanka has been at most times in response to the political crises in the country at a given moment; for instance the NGO, People's Action for Free and Fair Elections (PAFFREL), emerged in response to the 1982 referendum and the NGOs galvanized against the UNP in 1994 to support the victory of the People's Alliance (PA). However, as DeVotta (2004) argues, civil society in Sri Lanka has failed to stem the trajectory towards illiberalism and be an effective catalyst for social change.

5. The liberal discourse on peacebuilding efforts from a problem-solving framework: this body of literature is set within the framework of the global liberal peace discourse that emerged from the post-cold war. Its links to the dominant global political order have meant that it is set within a framework that seeks an interventionist and reformist agenda. From a critical theoretical position, this body of work takes a problem solving approach to the conflict.
6. An emerging critical liberal peacebuilding discourse: following the global discourse critiquing the liberal peacebuilding discourse, a small but significant body of critical scholarship has begun to emerge on the conflict. This body of work is set within critical and phenomenological theoretical frameworks and looks at the contextual variances that influence the success of a peacebuilding project.

The literature on liberal peace and liberal peacebuilding in Sri Lanka up to the 1980's is engaged through the lenses of political science and historiography. However, liberal peace principles have been in the Sri Lankan political discourse from the $19^{\text {th }}$ century, with the debates on separation of powers, state reform and electoral representation taking center stage (see Bandarage, 2009: p. 22; Edirisinha et al., 2008; Mendis, 1956). The use of "liberal peace" language from the ideological and policy framework of the modern liberal world order for promoting,

"individual and political freedom, representative democracy, tolerance and those economic arrangements which are most conducive to a free society" (Amaratunga, 1989: p. 3)

enters the political discourse only in the 1980s.

The labeling of the contemporary discourse, as liberal, however, succeeds in veiling the epistemological foundation of much of the previous political, historiographical and policy (social science) literature on attempts at creating equity for citizens of Sri Lanka. Most, political science, international relations, historiography, and administrative and foreign policy (see Jayawardane, 2004) literature on Sri Lanka have an epistemology of liberal peace and peacebuilding, although the works do not explicitly recognise this foundation. This is particularly relevant as even much of the state reform literature to emerge from a Marxist and "left" basis are grounded in a liberal framework (see Edirippulige, 2000: p.157). The overriding epistemological foundation of a liberal peace discourse has a combination of reasons. The formation of the modern Sri Lankan State has a basis in liberal governance through the separation of powers going back to the mid nineteenth century. The epistemological foundation of the Sri Lankan State, starting from its colonial heritage and the educational background of prominent intellectual-policy makers of the country ${ }^{7}$, to the influencing of sociological research in Sri Lanka, is reflected by the work to emerge from some of the main research institutions of the country (see de Silva, 2005: p. 536). 


\section{State reform and the ethnic crisis}

The most significant policy document that sets the foundation for the reformulation of this island state on liberal lines is the Colebrook-Cameroon reforms of 1833 (see Mendis, 1956; De Silva, 1959; Samaraweera, 1972). The Colebrooke-Cameron reforms introduced administrative, economic, judicial and legislative reforms that institutionalised the separation of powers. The reforms were significant and groundbreaking as they attempted to administratively unify a state whose overarching characteristic from its pre-modern times as a state had been disintegration and centrifugalism (de Silva, 2008).

The Colebrook-Cameron report was instrumental in introducing not only a liberal form of governance but in bringing about significant social changes for the welfare of the citizens of Ceylon, including access to education, civil rights and the promotion of the press (Mendis, 1956; Samaraweera, 1972; de Silva, 2008). The primary architect of the recommendations, Colebrooke, strove to reduce the powers of the Governor and insisted that all the subjects of the colony needed to be treated alike (Samaraweera, 1972).

With its roots in a liberal framework going back to the 1830's, the Sri Lankan State's history has been one of reformulating structures to ensure power separation and power sharing between communities, primarily through constitutional and electoral reform (Loganathan, 1996; Edrisinha et al., 2008; Coomaraswamy, 2012; Keerawella, 2014). This is reflected in the significant body of literature that grapples with state/constitutional reform efforts in Sri Lanka and their contribution to the ethnic crisis in Sri Lanka (see Ariyartane, 1972; Russell 1982; Amaratunga, 1989; Tiruchelvam, 1989; Edrisinha, et al., 2008; Pinnawala, 2014). The trajectory of this process can be noted as a use of liberal peacebuilding mechanisms by the elites of different ethnic groups to consolidate power within the state.

One liberal peacebuilding mechanism takes primacy in the framework through which the contestation for power and equity between communities in Sri Lanka is approached. This is the mechanism of state/constitutional reform through the devolution of power, as ensconced in federalism. The concept of a federal state first enters the local political discourse in the 1920s when it is proposed by the Kandyan Sinhalese to the British governors as an answer to the power contestations between the low country elites and the Kandyan Sinhalese elite (de Silva, 2008: p. 490). The concept of federalism as a means "to meet the just requirements of the different sections of [Ceylon's] inhabitants", enters the political debate with S. W. R. D. Bandaranaike's proposals for a "federation" in 1926 (Bandaranaike, S.W.R.D., in Edrisinha et al., 2008: p. 29), but is not recognised as a viable solution by the local politicians (de Silva, 2008: p. 491). The concept re-enters the political reform arena in the postcolonial era and culminates with the Federal Party's announcement of the Tamil people's right to a federal state at its first convention in Trincomalee in April 1951 (see Edrisinha et al., 2008: p. 208; Loganathan, 1996: p. 2).

From the early 1980s there have been several attempts to institute or explore equity between the communities, necessitated by the growing militarisation of the conflict. The first of these was the District Devolution Councils (DDC) of the late 1970s, spearheaded by President Jayewardene, which yet failed to be recognised as an answer to the national question by the Tamil parties as the DDCs were marked by strong links to the executive. The attempt at formalising the devolution of power, reached two important transition points in the $20^{\text {th }}$ century. The first was in the $13^{\text {th }}$ Amendment to the 1978 constitution, under the tutelage of the Government of India (formalised in the Indo-Lanka Accord of July 29, 1987 between India and Sri Lanka). The second was in the People's Alliance led GoSL efforts at constitutional change for a federal solution in 1995 (see Edirisinha et al., 2008: p. 275,409; Loganathan, 1996: p.167). The $13^{\text {th }}$ Amendment to the Constitution of Sri Lanka made Tamil an official language of Sri Lanka, established councils for each province, vested judicial powers up to the court of appeal and legislative/statutory powers on the provinces (Parliament, 1987; Tiruchelvem, 2000: p.191).

On August 3, 1995, President Kumaratunga proposed a devolution package, where the Sri Lankan state would comprise of a "Union of Regions" with police and land powers devolved to the regions (Bigdon, 2003: p.13; Singh \& Kukreja, 2014: p. 203). However, in the interweaving negotiations between the Sinhala polities, the draft constitution that emerged in August 1996, was unable to retain the spirit of the originally proposed devolution package, was faced with virulent opposition by the Sinhala polity and failed to meet the aspirations of the Tamil parties as well as reconcile the LTTE's demand for autonomy (see Bigdon, 2003; Singh \& Kukreja, 2014; Sahadevan, 2013). The proposed constitution bill of August 2000 was not passed by Parliament. All attempts at devolution have been virulently contested by Sinhala nationalist groups and have been one of the primary political platforms on which the nationalist Sinhala-Buddhist political parties enter the electoral contests (see Bigdon, 2003: p. 10; Loganthan, 1996; Uyangoda, 2011). The federal solution has taken different dimensions over the decades in the postcolonial battle for power and equity between ethnic communities in Sri Lanka; changing its dynamic from a non-militarised 
contestation, to a militarised contestation with the LTTE moving the demand to cessation, and a return to a nonmilitarised contestation in the post-war setting.

A significant body of work exits analysing the challenges of introducing devolution as a solution in Sri Lanka (see Amaratunga, 1989; Loganathan, 1996; Edrisinha, 2000; Jayatilleka, 2000; Jayatilaka, 2003; Edrisinha \& Welikala, 2008; Welikala, 2015). Furthermore, scholars use an analytical framework based on the need to rectify the state formation project of elite locals; they identify the need to correct the malformed state that failed to create equity for all its citizens if the conflict is to be resolved (Goodhand et al., 2011: p. 128). Tiruchelvam (2000: p.199) points out that in the final analysis, devolution of power and constitutional reform in Sri Lanka need to encounter and grapple with the nature of the Sri Lankan state, which is constitutionally entrenched as a unitary state. There is, therefore, a liberal consensus that devolution of power is the viable solution to the conflict of Sri Lanka (Moonesinghe in Edrisinha et al., 2008: p. 410; Verite Research, 2013). Yet, within this reform-led framework for a solution of the conflict, Uyangoda (2007: p. vii) acknowledges that the fundamental question of sharing state power in Sri Lanka has become non-negotiable. However, there is a continual presupposition that "...a federal re-constitution of the state along ethnic lines...." is necessary to embark on a political solution to the conflict (Uyangoda, 2007: p. ix). On the otherhand, the debate on federalism as a viable option has also generated work questioning the transportability of the federal concept to the local context (de Silva, 2000: p. 223). Such critiques of the transportability of the liberal mechanisms to the particular contextual needs of the Sri Lankan conflict have not become a dominant discourse in Sri Lanka.

One significant issue, however, resurfaces in the critical assessment of the unbridgeable division between the Tamil project for devolution and the Sinhala project for a unitary state, which is enacted in repeated cycles of backlashes by each community. This is a conceptual gap that has become the platform for political resistance and manipulation. The translation of the concept of "unitary" and "united" to Sinhala is ambiguous and any attempt to convey a federal solution within a united state has been translated both linguistically and politically (for the electoral advantage it offers) as an opening for a cessation (Edrisinha, 2000: p. 164).

\section{Secularism and the Sri Lankan State}

The concept of the secular state is one of the core principles on which the liberal thesis has evolved. The separation of religion from the state or offering equal status to all religions in Sri Lanka, however, does not follow the same trajectory as that of a state with an Enlightenment history.

A large body of work exists on the inter-relationship between the conflict and the politicisation of Buddhism, language and ethnic identity, and their continuing role as a contributor to the conflict (see Frerks \& Klem, 2005). The Sri Lankan State has evolved into one where the majority community consolidated power through a Sinhala-Buddhist nationalist ideology (DeVotta, 2007; Kapferer, 2012; Tambiah, 1992). Ethno-religious and linguistic nationalism of Sinhala Buddhism in Sri Lanka has been able to undermine attempts to reform the state (DeVotta, 2007), has given way to a violent, politicised sanga (Seneviratne, 1999), a dehumanising of the minorities and justifications for ethno-racist violence (DeVotta, 2007). The early colonial attempt to eschew the state's religious obligations towards Buddhism resulted in a later constant reclaiming of the state as a protector of Buddhism (de Silva, 2007). The revival of Buddhism in the $19^{\text {th }}$ century against the backdrop of the nationalist movement and the need to appease those promoting the former to manage the latter, resulted in the colonial rulers deliberately giving Buddhism state patronage (see de Silva, 2007: p.160) ${ }^{8}$.

Tambiah's seminal work goes on to document the inseparable connection that developed from the original Buddhist revival movement to the later nationalist movement, which finally colluded Buddhism with ethnic identity of the Sinhalese (Tambiah, 1992: p. 9). Wickremaratne argues that the answer to the question as to why a cohesive Ceylonese community did not develop, possibly "...lies in a variety of factors to do with the unevenness and paradoxes of reform and modernization" (Wickremaratne, 1999: p. 28). Therefore, the forces of change envisaged by colonial reform laid the foundation for two sets of nations within one state: one where the lines of division were economic and the other where the lines of division were ethnic (Wickremaratne, 1999: p. 29, 193). The dynamic between the state and Buddhism reached its epitome in the constitution of 1972 (Coomaraswamy, 2012: p. 129).

Of significant note in all the literature is the seeming inextricability of religion (primarily Buddhism) from the Sri Lankan State's egis and the challenges of relegating religion to a private space. At the same time, while it is in itself a reactive phenomenon, Sinhala Buddhist nationalism also generates the reactive project of Tamil nationalism (DeVotta, 2007: p. 14, 37). Explored from within a liberal peace framework, the state building project in Sri Lanka and its attendant failure to create equity and inclusion for all communities lies at the heart of the Sri Lankan conflict (Goodhand et al., 2011; Uyangoda, 2007). 


\section{Liberal peacebuilding in Sri Lanka}

In liberal peacebuilding terms, the 67-year timeline of the conflict (from 1948 to 2015) and the attendant search for a resolution has four phases. The first period from 1948 to the early 1980s was primarily made up of "peacemaking" efforts using democratisation and state/ constitutional reform mechanisms. These efforts were in response to the contestations by the Tamil polity over state reforms (constitutional mechanisms) that progressively undermined the principles of equity for the minorities by entrenching the position of the majority Buddhists/ Sinhalese as the dominant owners of political power and patronage. In this period, the elites of both ethnic groups engaged in a series of reconciliation attempts starting with the Bandaranaike-Chelvanayagam Pact of 1957 (de Silva, 2007; Liyanage \& Sinnathamby, 2007; Loganathan, 1996). These attempts failed for a complex combination of reasons. However, the striking feature of these failures is the Sinhala polity's ability to counter the impact of the reconciliation mechanisms through counter mobilisations of resistance through a range of political stakeholders and by state reform mechanisms.

The second period, from 1983-2006, is marked by a distinct peace process made up primarily of peacebuilding and efforts at state reform, and includes the intervention of external parties as mediators and negotiators. The Sri Lankan conflict formally takes on an external dimension from the early 1980s. This occurs first regionally, with India's role in the militarisation of the conflict and India's subsequent role as peacemaker and peacekeeper (see Jayawardane, 1995; Keerawella, 1995; Ratnatunga, 1988). A global engagement of the Western states begin with a development-aid role, followed by changes in geopolitics leading to a securitisation role, and finally the formal entry of the external facilitators as peacemakers (see Stokke, 2011: p. 2). In the 1990s, paralleling global academic work on liberal peacebuilding, a framework of liberal peace is explicitly used in exploring the ethnic conflict (see DeVotta, 2000; DeVotta \& Stone, 2008; Frerk \& Klem, 2005; Loganathan, 1996; Stokke \& Uyangoda, 2011; Wickramasinghe, 2006). The literature assesses the different phases of the war with the LTTE and the collapse of the many attempts to bring about a negotiated peace through peacemaking (DeVotta, 2004; DeVotta, 2009a; Orjuela, 2003; Sarvanathan, 2007; Stokke, 2007: 2009; Stokke \& Uyangoda, 2011; Uyangoda, 2008; Wickramasinghe, 2008; Wickramasinghe, 2009a).

During the period from 1983-2006, five efforts were made to resolve the conflict (Stokke, 2011: p.17).

1. The first externally mediated round of talks was called the Thimpu Talks, in 1985, between the GoSL and the main Tamil separatist groups: the Thimpu talks, with the first round of talks in July 1985 and the second round of talks in August, were the result of redefined relations between the Government of India and Sri Lanka with the death of Indian Prime Minister Indira Gandhi ${ }^{9}$.

2. The Indo-Sri Lanka accord of 1987: the significance of the accord lay in that it was established between the GoSL and another state, India. Therefore, the circumstances of the accord made it a realist engagement, although two liberal peace mechanisms, humanitarian engagement and state reform were used as the vehicle and outcome.

3. The informal talks between President Premadasa and the LTTE from 1989-1990 in Colombo: the primary motivation for the talks was the presence of the Indian Peace Keeping Force (IPKF), which both parties wanted withdrawn for political and military reasons. President Premadasa had come into power against the backdrop of the violent, $2^{\text {nd }}$ uprising of the JVP, which had ostensibly used the Indo-Lanka Accord and the presence of the IPKF in an attempt to consolidate power. President Premadasa wished to see the IPKF withdrawn as part of the efforts to conciliate the JVP. The LTTE wanted the IPKF withdrawn as it was being weakened by the militarily stronger Indian forces. The talks dissolved as the common objective of the withdrawal of the IPKF was achieved (Goodhand et al., 2011: p. 26; Uyangoda, 2015: p.111)

4. The talks between President Kumaratunga and the LTTE from 1994-1995: the three round of talks, which were held in Jaffna, involved little external mediation, but the GoSL used the assistance of the International Committee of the Red Cross (ICRC) (Goodhand et al., 2011, p. 25). The talks failed to achieve any reconciliation (except an agreement to desist from military hostilities during the talks) and was marked by fundamental differences of objectives: the GoSL wanted to deal with the root cause of the conflict while the LTTE wanted to deal with the consequences of the war (Uyangoda, 2015: p. 112).

5. The talks between Prime Minister Wickremasinghe's government and the LTTE with Norwegian mediation from 2002-2003. The peace process in Sri Lanka in this phase has generated a substantial body of scholarship from, primarily, a post-cold war liberal peace theoretical framework. Furthermore, as liberal peace is the ideology of the dominant global order, the Sri Lankan conflict in this phase attracted global intervention as well as scholars from the global north and the region. The primary reason for the failure of the Norwegian- 
led peace process in Sri Lanka has been identified as the weak position of the mediator and Norway's peace ownership approach (Hoglunad \& Svenson, 2011: p. 74; Goodhand et al., 2011: p. 134). In addition, the discourse has recognised that several other factors intervened and contributed to the collapse of the peace process. These include the limited contextual analysis and strategy that did not complement the highly fraught, complex setting (Goodhand et al., 2011: p. 134).

The two phases from 2006 to May, 2009 and May, 2009 to 2015, marked the militarisation of the conflict, the disengagement from peacebuilding and the end of the war where the GoSL gradually disengaged itself from the liberal peace framework. The literature that has emerged since the end of the war in 2009 highlights the trends toward ethno-nationalism and the lost opportunity for reconciliation in the face of politicisation of the reconciliation process (Keerawella, 2010; 2013; Thiranagama, 2013; Wickramasinghe, 2009). There is also a small body of work that questions the impact of liberal peacebuilding on peace and the need for contextualising the mechanisms (Goodhand \& Lewer, 1999; Goodhand \& Walton, 2009; Goodhand \& Korf, 2011; Jirasinghe, 2016 ; 2017) and on the local and the beneficiaries of peace (Orjuela, 2008) in Sri Lanka which have been engaged with from a critical framework. The history of the Sri Lankan liberal peacebuilding experience has been cited as a case in point of the unintended repercussions and consequences of interventionist peacebuilding projects (Goodhand et al., 2011; Goodhand \& Walton, 2009).

\section{CONCLUSION}

\section{Challenges to the liberal peacebuilding project}

In an evaluation of the chronological progress of liberal peacebuilding in Sri Lanka, it is possible to identify the direct influences from the parallel global literature as well as the direct influences of key global theorists ${ }^{10}$. The post cold war peacebuilding phase is dominated by the need to end the war followed by the parallel objective of ending the conflict by politically consolidating equity to the minority ethnic groups. The two objectives become a two-pronged strategy in the liberal peacebuilding framework.

However, peacebuilding failed to achieve the first objective, given the nature of the militarised contest between the LTTE and the GoSL (see Goodhand \& Korf, 2011). Peacebuilding also failed to garner support from the local stakeholders, especially the Sinhala-Buddhist electorate, for a framework for equity for ethnic minorities (Uyangoda, 2011; Jayatilleka, 2013). Both failures have been analysed in the literature by grappling with the mechanics of the failed peacebuilding projects and the ethno-religious-political-economic background of the conflict. This critique of peacebuilding explores, for instance, the constant creation and recreation of an ethnocratic state (Uyangoda, 2011), the patterns of neo-liberal market reform (Venugopal, 2011), and the problems of peace ownership in an externally negotiated peace process (Hogland \& Svensson, 2011), as contributory causes for the failure of liberal peacebuilding.

Of significance in the post cold war framework in the Sri Lankan peacebuilding project is the attempt to move away from making peacebuilding primarily a statereform project to one that includes structural reform as well, while offering ownership of peace to the grassroots. The Sudu Nelum (White Lotus) movement of the 1990s attempted to give peace ownership to the locals and at first glance has been evaluated as having been successful in ensuring a local buy-in (BandaranaikeKumaratunga, 1995; Handunnhetti, 1998; Perera, 2015). However, empirical work has concluded that the buyin was superficial and that the project was sustained by governmental and civil society organisational support (Orjuela, 2003: p. 200; 2008). The continuing challenges of the liberal peacebuilding project in Sri Lanka point to the need for a critical exploration of the epistemological and ontological assumptions on which the project had been built.

\section{Lacunas in the literature and insights}

Much of the literature on liberal peace and peacebuilding in Sri Lanka in the past have engaged with peacebuilding through a problem-solving framework instead of a critical framework (Cox, 1981). There is a body of scholarship emerging from within a critical/constructivist perspective, examining the impact of liberal peacebuilding on liberal peace and peace in Sri Lanka (Orjuela, 2008; Goodhand \& Korf, 2011). The assumption throughout the peacebuilding processes in postcolonial Sri Lanka has been, in the early phase, that the conflict (then an elites' conflict), could be resolved top-down through reform mechanisms. In its mature phase, when the conflict has been politicised within the electoral discourse, it has been approached from the post-cold war peacebuilding framework of a multi-pronged approach including bottom-up peace creation and ownership mechanisms and top-down reforms.

The global critique highlights the lacunas as well as possible agendas for research on liberal peacebuilding in a case such as Sri Lanka. The most relevant in this lacuna is the need for case-specific literature based within the critical theoretical framework, which brings in the "local" 
and the "everyday" to the forefront (Richmond \& Mac Ginty, 2014). In terms of methodology, Richmond \& Mac Ginty emphasise that it is,

"...prudent to get beyond the obsession with levels of analyses, which are of limited worth if we do not seriously examine the epistemologies upon which they are based. Each of the levels is a construction behind which lies a story of our place in the world" (Richmond \& Mac Ginty, 2014: p. 14).

As a state in conflict, the postcolonial Sri Lankan case encapsulates many of the ongoing current debates, dilemmas and critiques identified in the global literature on liberal peace and peacebuilding. Questions of intervention versus sovereignty, liberal assumptions versus local ontologies of being and the hegemony of intervention versus resistance of the local, all have at some point been issues that have been pertinent to the Sri Lankan liberal peace context. While a small handful of scholars have started to point out the ensuing repercussions when peacebuilding projects encountered the local context, there is a lacuna of critical work on the nature of agency, the actualisation of concepts such as peace, the nature of the state and the manner in which these interact with a liberal peacebuilding project and local resistance of the project.

\section{ACKNOWLEDGEMENT}

The author wishes to express her gratitude to Amal Jayawardane, Emeritus Professor of International Relations, University of Colombo and Senior Professor, General Sir John Kotelawala Defence University, and to Gamini Keerawella, Emeritus Professor of History, University of Peradeniya and former Deputy Ambassador of Sri Lanka to the US and the Director of the RCSS, for their invaluable guidance and supervision of her doctoral research. Also to Mr. Tissa Jayatilaka, former Executive Director of the US-SL Fulbright Commission, for his support of her research and writing. The researcher is sincerely grateful to the anonymous reviewers and editors of this article, whose comments, suggestions and meticulous editorial support made this version possible.

\section{END NOTES}

1. Fukuyama, 1992: p. 29.

2. See Ikenberry, 2009; Sabaratnam, 2011: p. 13; Mac Ginty, 2011: p. 5.

3. Despite the different core elements to it, there is one singular essence that can be drawn from classical liberalism that has persisted into the contemporary variations of liberalism. This pertains to the relationship between the state, the citizens and religion. Liberalism "does not and cannot" cede authority over questions pertaining to the relationship between the state and the citizens (issues of politics) to religion (Owen, 2004: p. 325).

4. Radin (2012: p. 11) describe the International Community as "...states and organizations that cooperate to provide assistance to post conflict and developing societies. The most prominent members of the international community for many operations include the United States, United Kingdom, France, Germany, Italy and Russia; and organizations such as the UN, EU, NATO and the OSCE. The International Community may form ad hoc or informal organizations to pursue its goals such as the contact group in the Balkans". This article uses Peltonen's (2014) definition of the IC as a dynamic, context driven, problem driven and less state centric grouping at the level of the international system. In relation to Sri Lanka during and after the military conclusion of the war, the international system was ideologically divided, with the United States, United Kingdom, France, Japan and India aligning within a liberal framework as the IC and states such as Russia and China aligning with the Government of Sri Lanka (GoSL) as allied states.

5. Ylimaz (2005) notes that while the UN has been engaging in peacekeeping, the precise charter mention is much debated.

6. See Alagappa (2004) for a discussion on the conceptual definition of civil society (of relevance here is the two strands in the contemporary definitions - the liberal democratic and the new left) and their role in Asia.

7. S. W. R. D. Bandaranaike and Chanaka Amaratunga (both proponents of federalism) were educated at Christ Church and University College of Oxford University, respectively. Colvin R. de Silva (one of the founder members of the Marxist, Lanka Sama Samaja Party), read for his doctoral dissertation on the British in Ceylon at Kings College, University of London. S. A. Wickremasinghe (the founder of the Communist Party), did his postgraduate studies in medicine at the University of London, and Phillip Gunawardena (a founder member of the Lanka Sama Samaja Party) read economics at the University of Wisconsin-Madison.

8. See also, Wickremaratne (1999: p. 194) for comments on the British governors who were scholars and sympathisers of the Buddhist philosophy. 
9. It is noteworthy that, while the 2002 Norwegian mediated talks are highlighted as the talks that gave parity of status to both parties (see Stokke, 2011), the battle of parity and legitimacy by the representatives of the Tamil parties (which was 6 parties including the LTTE) had been recognised by the Bhutanese Government in 1985, too. As a result, both delegations had been treated equally, extending even to having members of both delegations being frisked at the talks, which included the brother of President Jayewardene, Harry Jayewardene (see Loganathan, 1996: p. 103).

10. Sri Lanka has been a laboratory case of post-cold war liberal peacebuilding policy and research. It has attracted well know scholars and policy makers such as Galtung, Lederach and Garth Evans to be directly involved in the peacebuilding processes as researchers and advocates.

\section{REFERENCES}

Ahmad, A. (1992) In Theory: Classes, nations, literatures, London: Verso.

Alagappa, M. (2004) Civil Society and Political Change in Asia: Expanding and Contracting Democratic Space, Stanford, California: Stanford University Press [Online] Available from https://books.google.lk/ [Accessed: 25 $5^{\text {th }}$ January 2016].

Amaratunga, C. (ed) (1989) Ideas for Constitutional Reform, Dehiwala, Sri Lanka: The Council for Liberal Democracy.

Archibugi, D. (1995) Emanuel Kant, Cosmopolitan Law and Peace, European Journal of International Relations, 1(14), pp: 429 -456 [Online] Available from http://www.danielearchibugi. org/downloads/papers/2017/11/Cosmopolitan_Law.pdf [Accessed: $27^{\text {th }}$ October 2015].

Ariyaratne, R. A. (1972) Communal Conflict in Ceylon Politics and the Advance Towards Self-Government 1917-1932, Unpublished doctoral dissertation, Cambridge: University of Cambridge.

Bandarage, A. (2009) The Separatist Conflict in Sri Lanka: Terrorism, Ethnicity Political Economy, Oxon: Routledge.

Bandaranaike-Kumaratunga, C. (1995) The address made at the inaugural meeting of the "Sudu Nelum", [Online] $8^{\text {th }}$ July 1995, Colombo, Available from: http://www.info. gov.lk/execpres/speeches/1995/19950708SuduNelum.html [Accessed: $8^{\text {th }}$ August 2015].

Barnett, M. (1997) The UN Security Council, Indifference and Genocide in Rwanda, Cultural Anthropology, 12(4), pp: 551-578 [Online] Available from: http://www.jstor.org/ stable/656636 [Accessed: $3^{\text {rd }}$ June 2013].
Barnett, M. (2006) Building a Republican Peace: Stabilizing States after War, International Security, 30(4), pp: 87-112 [Online] Available from https://www.jstor.org/ stable/4137530?seq=1\#page_scan_tab_contents [Accessed: $12^{\text {th }}$ July 2013].

Barnett, M. (2009) Evolution Without Progress: Humanitarianism in a World of Hurt, International Organization, 63(4), pp: 621-663 [Online] Available from https://www. jstor.org/stable/40345951?seq=1\#page_scan_tab_contents [Accessed: 27 $7^{\text {th }}$ October 2015].

Bass, G. J. (2004) Jus Post Bellum, Philosophy \& Public Affairs, 32(4), pp: 384-412 [Online] Available from: http:// www.jstor.org/stable/3557994 [Accessed: $24^{\text {th }}$ January 2014].

Beitz, C. R. (2000) Rawls's Law of Peoples, Ethics, 110(4), pp: 669-696 [Online] Available from http://www.jstor.org/ stable/10.1086/233369 [Accessed: $23^{\text {rd }}$ January 2014].

Bell, C. \& O' Rourke, C. (2007) The People's Peace? Peace Agreements, Civil Society, and Participatory Democracy, International Political Science Review / Revue Internationale de Science Politique, 28(3), pp: 293-324 [Online] Available from: http://www.jstor.org/stable/20445096 [Accessed: 27 $7^{\text {th }}$ October 2015].

Bellamy, A. J. (2008) The Responsibilities of Victory: "Jus Post Bellum" and the Just War, Review of International Studies, 34(4), pp: 601-625 [Online] Available from: http://www.jstor. org/stable/40212494 [Accessed: $24^{\text {th }}$ February 2014].

Beng-Huat, C. (1994) Arrested Development: democratisation in Singapore, Third World Quarterly, 15(4), pp: 655-668.

DOI: https://doi.org/10.1080/01436599408420402

Beng-Huat, C. (2000) Postcolonial Sites, Global Sites and Fashion Codes: a case-study of power cheongsams and other clothing styles in modern Singapore, Postcolonial Studies, 3(3), pp: 279-292.

DOI: https://doi.org/10.1080/13688790020005029

Bigdon, C. (2003) Decentralization, Federalism and Ethnic Conflict in Sri Lanka: An assessment of federal proposals, devolution policy and the realities of recognition of minorities at the local level, Heidelberg: South Asia Institute, University of Heidelberg [Online] Available from: http://archiv.ub.uniheidelberg.de/volltextserver/4125/1/hpsacp14.pdf [Accessed: $26^{\text {th }}$ December 2015].

Blattman, C. \& Miguel, E. (2010) Civil War, Journal of Economic Literature, 48(1), pp: 3-57 [Online] Available from: http://www.jstor.org/stable/40651577 [Accessed: 6 $^{\text {th }}$ March 2013].

Brown, G., Langer, A. \& Stewart, F. (2008) Typology of PostConflict Environments: An Overview, CRISE Working Paper, 53, Oxford: Centre for Research on Inequality, Human Security and Ethnicity. 
Call, C. T. \& Cousens, E. M. (2007) Ending Wars and Building Peace, Coping with Crisis Working Paper Series, New York: International Peace Academy [Online] Available from: http:// www.ipinst.org/2007/03/ending-wars-and-building-peace [Accessed: 27 ${ }^{\text {th }}$ October 2015].

Call, C. T. (2008) Knowing Peace When You See It: Setting Standards for Peacebuilding Success, Civil Wars, 10(2), pp: 173-94.

DOI: https://doi.org/10.1080/13698240802062747

Chandler, D. (2009) Unravelling the Paradox of 'The Responsibility to Protect', Irish Studies in International Affairs, 20, pp: 27-39 [Online] Available from http://www.jstor.org/ stable/25735148 [Accessed: $28^{\text {th }}$ March 2013].

Chandler, D. (2007) The Possibilities of Post-Territorial Political Community, Area, 39(1), pp: 116-119 [Online] Available from http://www.jstor.org/stable/20004593 [Accessed: 28 ${ }^{\text {th }}$ March 2013].

Chatterjee, P. (2014) Empire and Nation: Essential Writings 1985-2005, Ranikhet:Permanent Black/Columbia University Press.

Chaudoin, S., Milner, H. V. \& Tingley, D. H. (2010) The Center Still Holds: Liberal Internationalism Survives, International Security, 35(1), pp: 75-94 [Online] Available from http://www. jstor.org/stable/40784647 [Accessed: 22 ${ }^{\text {nd }}$ January 2014].

Coomaraswamy, R. (2012) The 1972 Republican Constitution of Sri Lanka in the Postcolonial Constitutional Evolution of Sri Lanka, In Welikala, A. (ed) The Sri Lankan Republic at 40: Reflections on Constitutional History, Theory and Practice, Colombo: Centre for Policy Alternatives.

Cox, R. W. (1981) Social Forces, States and World Orders: Beyond International Relations Theory, Millennium Journal of International Studies, 10(2), pp: 126 -155 [Online] Available from: http://journals.sagepub.com/doi/abs/10.1177/030582988 10100020501 [Accessed: $27^{\text {th }}$ July 2015].

Dafoe, A. (2011) Statistical Critiques of the Democratic Peace: Caveat Emptor, American Journal of Political Science, 55(2), pp: 247-262 [Online] Available from http://www.jstor.org/ stable/23025049 [Accessed: $29^{\text {th }}$ January 2014].

Dahl, E. S. (2012) Oil and Water? The Philosophical Commitments of International Peace Studies and Conflict Resolution, International Studies Review, 14(2), pp: 240-272 [Online] Available from http://www.jstor.org/stable/23279995 [Accessed: 24 ${ }^{\text {th }}$ January 2014].

Dawson, C. (1954) Historic Origins of Liberalism, The Review of Politics, 16(3), pp: 267-182 [Online] Available from http:// www.jstor.org/stable/1405143 [Accessed: $8^{\text {th }}$ January 2014].

De Roover, J. \& Balagangadhara, S. N. (2008) John Locke, Christian Liberty, and the Predicament of Liberal Toleration, Political Theory, 36(4), pp: 523-549 [Online] Available from http://www.jstor.org/stable/20452650 [Accessed: 21 ${ }^{\text {st }}$ April 2014].

De Roover, J., Claerhout, S. \& Balagangadhara, S. N. (2011) Liberal Political Theory and the Cultural Migration of Ideas: The Case of Secularism in India, Political Theory, 39(5), pp: 571-599 [Online] Available from http://www.jstor.org/ stable/23036074 [Accessed: 7th May 2014].

de Silva, J. (2005) Globalisation and the Besieged Nation: The Effects of Collective Violence on Sociological and Anthropological Research in Post-colonial Sri Lanka, Sociological Bulletin, 54(3) Special Issue on South Asia: the state of sociology: issues of relevance and rigour, pp: 533-550 [Online] Available from http://www.jstor.org/stable/23620624 [Accessed: $16^{\text {th }}$ March 2015].

de Silva, K. M. (1959) The Colebrook Cameron Reforms, Ceylon Journal of Historical and Social Studies (CJHSS), 2(2), pp: 243-257.

de Silva, K. M. (2000) Federal Option and its Alternatives, In de Silva, K. M. \& Peiris, G. H. (eds), Pursuit of Peace in Sri Lanka: Past Failures and Future Prospects, pp: 203-229, Kandy:ICES.

de Silva, K. M. (2008) A History of Sri Lanka, Colombo: VijithaYapa.

de Soysa, I. (2002) Paradise Is a Bazaar? Greed, Creed and Governance in Civil War, 1989-99, Journal of Peace Research, 39(4) Special Issue on Civil War in Developing Countries, pp: 395-416 [Online] Available from http://www.jstor.org/ stable/1555274 [Accessed: $6^{\text {th }}$ November 2015].

DeVotta, N. \& Stone, J. (2008) Jathika Hela Urumaya and Ethno-Religious Politics in Sri Lanka, Pacific Affairs, 81(1), pp: 31-51 [Online] Available from http://www.jstor.org/ stable/40377481 [Accessed: $6^{\text {th }}$ March 2013].

DeVotta, N. (2000) Control Democracy, Institutional Decay, and the Quest for Eelam: Explaining Ethnic Conflict in Sri Lanka, Pacific Affairs, 73(1), pp: 55-76 [Online] Available from http://www.jstor.org/stable/2672284 [Accessed: $6^{\text {th }}$ March 2013].

DeVotta, N. (2004) Sri Lanka: Ethnic Domination, Violence and Illiberalism, In Alagappa, M. (ed) Civil Society and Political Change in Asia: Expanding and Contracting Democratic Space, pp: 292-323, Stanford, California: Stanford University Press.

DeVotta, N. (2009a) Sri Lanka at Sixty: A Legacy of Ethnocentrism and Degeneration, Economic and Political Weekly, 44(5), p: 46-53 [Online] Available from http://www. jstor.org/stable/40278459 [Accessed: $6^{\text {th }}$ March 2013].

DeVotta, N. (2009b) The Liberation Tigers of Tamil Eelam and the Lost Quest for Separatism in Sri Lanka, Asian Survey, 49(6), pp: 1021-1051 [Online] Available from http://www. 
jstor.org/stable/10.1525/as.2009.49.6.1021 [Accessed: $9^{\text {th }}$ December 2014].

DeVotta, N. (2007) Sinhalese Buddhist Nationalist Ideology: Implications for Politics and Conflict Resolution in Sri Lanka, Washington: East West Center [Online] Available from: https:// www.eastwestcenter.org/fileadmin/stored/pdfs/ps040.pdf [Accessed: 25 $5^{\text {th }}$ January 2016].

Doyle, M. W. (1983) Kant, Liberal Legacies, and Foreign Affairs: Part 2, Philosophy \& Public Affairs, 12(4), pp: 323-353 [Online] Available from http://www.jstor.org/stable/2265377 [Accessed: $6^{\text {th }}$ March 2013].

Doyle, M. (1992) Liberal Democracy and the Future of International Security, Newsletter of PEGS, 2(3), pp: 12-13 [Online] Available from: http://www.jstor.org/stable/20710579 [Accessed: $6^{\text {th }}$ February 2013].

Doyle, M. W. \& Sambanis, N. (2000) International Peacebuilding: A Theoretical and Quantitative Analysis, The American Political Science Review, 94(4), pp: 779-801 [Online] Available from http://www.jstor.org/stable/2586208 [Accessed: $6^{\text {th }}$ November 2015].

Doyle, M. W. \& Sambanis, N. (2007) What Kind of Security? Afghanistan and Beyond, International Journal, 62(3), pp: 494-518 [Online] Available from http://www.jstor.org/ stable/40184857 [Accessed: $23^{\text {rd }}$ July 2015].

Doyle, M. W. (2005) Three Pillars of the Liberal Peace, The American Political Science Review, 99(3), pp: 463-466 [Online] Available from: http://www.jstor.org/stable/30038953 [Accessed: $6^{\text {th }}$ March 2013].

Doyle, M. W. (2006) One World, Many Peoples: International Justice in John Rawls's the Law of Peoples, Perspectives on Politics, 4(1), pp: 109-120 [Online] Available from: https:// www.jstor.org/stable/3688631?seq=1\#page_scan_tab_contents [Accessed: $3^{\text {rd }}$ June 2013].

Duffield, M. (2007) Development, Territories, and People: Consolidating the External Sovereign Frontier, Alternatives: Global, Local, Political, 32(2), pp: 225-246 [Online] Available from http://www.jstor.org/stable/40645211 [Accessed: $11^{\text {th }}$ February 2014].

Duke, S. \& Coutier, A. (2009) EU Peacebuilding: concepts, players and instruments, Working Paper No. 33, Belgium: Leuven Centre for Global Governance Studies [Online] Available from https:/ghum.kuleuven.be/ggs/publications/ working_papers/new_series/wp31-40/wp33.pdf [Accessed: $25^{\text {th }}$ January 2016].

Edirippulige, S. K. (2000) Ethnic Conflict in Sri Lanka: Obstacles to the Peace Process, Unpublished doctoral dissertation, Auckland, New Zealand: University of Auckland [Online] Available from http://hdl.handle.net/2292/723 [Accessed: 27 ${ }^{\text {th }}$ June 2013].
Edrisinha, R. \& Welikala, A. (2008) Essays on Federalism in Sri Lanka, Colombo: Centre for Policy Alternatives.

Edrisinha, R., Gomez, M., Thamilmaran V. T. \& Welikala, A. (2008) Power Sharing in Sri Lanka: Constitutional and Political Documents 1926-2008, Colombo and Berlin: Center for Policy Alternatives and the Berghof Foundation for Conflict Studies.

Edrisinha, R. (2000) Federalism and the Case for Radical Constitutional Reform in Sri Lanka, In de Silva, K. M. \& Peiris, G. H. (eds) Pursuit of Peace in Sri Lanka: Past Failures and Future Prospects, pp: 163-179, Kandy: ICES.

Evans, G. (2007) The Limits of State Sovereignty: the Responsibility to Protect in the $21^{\text {st }}$ Century, Eighth Neelam Tiruchelvam Memorial Lecture [Online] 29 ${ }^{\text {th }}$ July 2007, Colombo: ICES, Available from: http://old.crisisgroup.org/ en/publication-type/speeches/2007/evans-the-limits-of-statesovereignty-the-responsibility-to-protect-in-the-21 st-century. html [Accessed: 10 ${ }^{\text {th }}$ November 2014].

Ferejohn, J. \& Rosenbluth, F. M. (2008) Warlike Democracies, The Journal of Conflict Resolution, 52, pp: 3-38 [Online] Available from: http://www.jstor.org/stable/27638593 [Accessed: $3^{\text {rd }}$ February 2015]

Fernando, U. (2014) Presidential Election and Civil Society, Paper delivered at 'Panel Discussion- Priorities for the President: Civil Society Perspective', Colombo: ICES, $17^{\text {th }}$ December 2014.

Fortier, J. (2010) Can Liberalism lose the Enlightenment?, The Journal of Politics, 72(4), pp: 1003-1013 [Online] Available from: http://www.jstor.org/stable/40926749 [Accessed: $7^{\text {th }}$ May 2014].

Fortna, V. P. (2004) Does Peacekeeping keep Peace? International Intervention and the Duration of Peace after Civil War, International Studies Quarterly, 48(2), pp: 269-292 [Online] Available from: http://www.jstor.org/stable/3693574 [Accessed: 23 ${ }^{\text {rd }}$ July 2015].

Franke, M. F. N. (1995) Immanuel Kant and the (Im)Possibility of International Relations Theory, Alternatives: Global, Local, Political, 20 (3), pp: 279-322 [Online] Available from http:// www.jstor.org/stable/40644836 [Accessed: $21^{\text {st }}$ April 2014].

Freidman, R. (2015) Restorative Justice and Truth Commissions in Sierra Leone and Peru, Lecture, $11^{\text {th }}$ August 2015, Colombo: ICES.

Frerks, G. \& Klem, B. (2005) Dealing with Diversity: Sri Lankan Discourses on Peace Conflict, Clingendael: The Netherlands Institute of International Relations.

Fukuyama, F. (1995) Reflections on the End of History, Five Years Later, History and Theory, 34(2) Theme Issue 34: World Historians and Their Critics, pp: 27-43 [Online] Available from: http://www.jstor.org/stable/2505433 [Accessed: $27^{\text {th }}$ January 2015]. 
Fukuyama, F. (1992) The End of History and the Last Man, New York: Free Press [Online] Available from: http://www.socialsciences-and-humanities.com/PDF/The-End-of-History-andthe-Last-Man-.pdf [Accessed: $25^{\text {th }}$ January 2016]

Galtung, J. (1985) Twenty-Five Years of Peace Research: Ten Challenges and Some Responses, Journal of Peace Research, 22(2), pp: 141-158 [Online] Available from: http://www.jstor. org/stable/424240 [Accessed: $15^{\text {th }}$ January 2014].

Galtung, J. (1981) Social Cosmology and the Concept of Peace, Journal of Peace Research,18(2) Special Issue on Theories of Peace, pp: 183-199 [Online] Available from: http://www.jstor. org/stable/424210 [Accessed: $31^{\text {st }}$ January 2014].

Galtung, J. (1976) Three Approaches to Peace: Peacekeeping, Peacemaking, and Peacebuilding, Peace, War and Defense: Essays in Peace Research, II, pp: 297-298.

Galtung, J. (1969) Violence, Peace, and Peace Research, Journal of Peace Research, 6(3), pp: 167-191 [Online] Available from: http://www.jstor.org/stable/422690 [Accessed: $5^{\text {th }}$ February 2014]

Gheciu, A. \& Welsh, J. (2009) The Imperative to Rebuild: Assessing the Normative Case for Postconflict Reconstruction, Ethics and International Affairs, pp: 121-147.

DOI: https://doi.org/10.1111/j.1747-7093.2009.00203.x

Ghosh, P. S. (1995) Cooperation and Conflict in South Asia, Delhi: Manohar.

Glaser, T. (1997) Summary: John Paul Lederach, "Introduction," and "A Framework for Building Peace", Preparing for Peace: Conflict Transformation Across Cultures, pp: 3-23, Syracuse, New York: Syracuse University Press [Online] Available from: http://www.colorado.edu/conflict/transform/lederach2.htm [Accessed: $5^{\text {th }}$ February 2014].

Gombrich, R. \& Obeyesekere, G. (1988) Buddhism Transformed: Religious Change in Sri Lanka, Princeton, New Jersey: Princeton University Press [Online] Available from: https://books.google.lk [Accessed: 25 ${ }^{\text {th }}$ January 2016].

Goodhand, J. \& Korf, B. (2011) Caught in the Peace Trap, In Goodhand, J., Spencer, J. \& Korf, B. (eds) Conflict and Peacebuilding in Sri Lanka: Caught in the peace trap?, Oxon: Routledge, pp: 1-15 [Online] Available from: https://books. google.lk [Accessed: 25 $5^{\text {th }}$ January 2016].

Goodhand, J. \& Lewer, N. (1999) Sri Lanka: NGOs and PeaceBuilding in Complex Political Emergencies, Third World Quarterly, 20(1) Complex Political Emergencies, pp: 69-87 [Online] Available from: http://www.jstor.org/stable/3993183 [Accessed: $6^{\text {th }}$ March 2013].

Goodhand, J. \& Walton, O. (2009) The Limits of Liberal Peacebuilding? International Engagement in the Sri Lankan Peace Process, Journal of Intervention and Statebuilding, 3(3), pp: 303-323 [Online] Available from: https://www.tandfonline. com/doi/abs/10.1080/17502970903086693 [Accessed: 27 $7^{\text {th }}$ June 2013].

Goodhand, J., Klem, B. \& Sørbø, G. (2011) Pawns of Peace: Evaluation of Norwegian Peace Efforts in Sri Lanka, 19972009 (commissioned by Norad Evaluation Department, Report 5/2011), Oslo, Norway: Norwegian Organization for Development Cooperation (NORAD) [Online] Available from: http://www.oecd.org/countries/srilanka/49035074.pdf [Accessed: 25 $5^{\text {th }}$ January 2016].

Gosh, P. (2011) International Relations ( $2^{\text {nd }}$ ed), New Delhi: PHI Learning.

Hamieh, C. \& Mac Ginty, R. (2010) A very political reconstruction: governance and reconstruction in Lebanon after the 2006 war, Disasters, 34, pp: S103-S123.

DOI: https://doi.org/10.1111/j.1467-7717.2009.01101.x

Handunnhetti, D. (1998) Sudu nelum: Bridging the Ethnic Divide, Sunday Times, $8^{\text {th }}$ March 1998 [Online] Available from: http://www.sundaytimes.lk/980308/plus10.html [Accessed: $15^{\text {th }}$ January 2016].

Harrison, E. (2010) The democratic peace research program and system-level analysis, Journal of Peace Research, 47(2), pp: 155-165 [Online] Available from: http://www.jstor.org/ stable/25654552 [Accessed: $21^{\text {st }}$ April 2014].

Hattotuwa, S. (2007) Landmark Agreements/ Proposals for Resolving the Ethnic Conflict in Sri Lanka, Colombo: Center for Policy Alternatives [Online] Available from: http:// cpalanka.org/wp-content/uploads/2007/8/mark_Agreements_ in_Sri_Lanka.pdf [Accessed: $26^{\text {th }}$ December 2015].

Helman, G. B. \& Ratner, S. R. (1992-1993) Saving Failed States, Foreign Policy, 89, pp: 3-20 [Online] Available from: http://www.jstor.org/stable/1149070 [Accessed: 11 $11^{\text {th }}$ February 2014].

Hoglund, K. \& Svensson, I. (2011) Fallacies of the Peace Ownership Approach: Exploring Norwegian Mediation in Sri Lanka, In Stokke, K. \& Uyangoda, J. (eds) Liberal Peace in Question: Politics of State and Market Reform in Sri Lanka, pp: 63-75, UK: Anthem Press.

Ikenberry, J. G. (2009) Liberal Internationalism 3.0: America and the Dilemmas of Liberal World Order, Perspectives on Politics,7(1), pp: 71-87 [Online] Available from: http://www. jstor.org/stable/40407217 [Accessed: $3^{\text {rd }}$ April 2013].

International Institute for Strategic Studies (IISS) (2014) Armed Conflicts Database [Online] Available from: https://acd. iiss.org/ [Accessed: $11^{\text {th }}$ February 2014].

Ismail, O. (2008) Power elites, war and postwar reconstruction in Africa: Continuities, discontinuities and paradoxes, Journal of Contemporary African Studies, 26(3), pp: 259-278.

DOI: https://doi.org/10.1080/02589000802332457 
Jayatilaka, T. (2003) Why Federalism - American or Otherwise - may not be a solution to the national problem of Sri Lanka, Presentation made to the American Studies Association of Sri Lanka, $29^{\text {th }}$ March 2003, Colombo: Lotus Room, Galle Face Hotel.

Jayatilleka, D. (2000) Crisis of Devolution: 1988-1989, In de Silva, K. M. \& Peiris, G. H. (eds) Pursuit of Peace in Sri Lanka: Past Failures and Future Prospects, pp: 87-130, Kandy: International Centre for Ethnic Studies.

Jayatilleka, D. (2013) Long War: Cold Peace - Conflict and Crisis in Sri Lanka, Colombo: Vijitha Yapa.

Jayawardane, A. (1995) The Response of External Powers to India's Involvement in Sri Lanka, In Werake, M. \& Jayasekera, P. V. J. (eds) Security Dilemmas of a Small State: Part Two Internal Crisis and External Intervention in Sri Lanka, pp: 232249, Kandy: International Centre for Ethnic Studies.

Jayawardane, A. (ed) (2004) Documents on Sri Lanka's Foreign Policy: 1947-1965, Colombo: Regional Center for Strategic Studies (RCSS).

Jayawardena, K. (2000) Nobodies to Somebodies - The Rise of the Colonial Bourgeoisie in Sri Lanka, Colombo: Social Scientists' Association and Sanjiva Books.

Jirasinghe, R. C. (2016) The International Community's Intervention during the Conclusion of the War in Sri Lanka, Strategic Analysis, 40 (4).

DOI: https://doi.org/10.1080/09700161.2016.1184789

Jirasinghe, R. C. (2017) Liberal Peacebuilding in Sri Lanka During and After the Military Conclusion of the War, Unpublished doctoral dissertation, Sri Lanka: University of Colombo.

Kadir, S. (2004) Singapore: Engagement and Autonomy within the Political Status Quo, In Alagappa, M. (ed) Civil Society and Political Change in Asia: Expanding and Contracting Democratic Space, pp: 324-356, Stanford, California: Stanford University Press [Online] Available from: https://books.google. 1k/ [Accessed: $25^{\text {th }}$ January 2016].

Kapferer, B. (2012) (revised edition) Legends of people, myths of state: violence, intolerance, and political culture in Sri Lanka and Australia, Oxford, New York: Berghahn Books [Online] Available from: https://books.google.lk/ [Accessed: $15^{\text {th }}$ January 2016].

Kapitan, T. (2006) Self-Determination and International Order, The Monist, 89(2), pp: 356-370 [Online] Available from: http:// www.jstor.org/stable/27903983 [Accessed: $21^{\text {st }}$ January 2014].

Kaye, J. \& Béland, D. (2009) The Politics of Ethnicity and Post-conflict Reconstruction: The case of Northern Ghana, Journal of Contemporary African Studies, (27) 2, pp: 177-200. DOI: https://doi.org/10.1080/02589000902867253
Keerawella, G. (1995) India's Involvement in Sri Lanka's Ethnic Conflict: Objectives and Modus Operandi, 1980-1990, In Werake, M. \& Jayasekera, P. V. J. (eds) Security Dilemmas of a Small State: Part Two -Internal Crisis and External Intervention in Sri Lanka, pp: 276-314, Kandy: International Centre for Ethnic Studies.

Keerawella, G. (2010) Military defeat of the LTTE is by no means a defeat of the Tamil people, Daily FT, $27^{\text {th }}$ November 2010 [Online] Available from: http://www.ft.lk/opinion/ military-defeat-of-the-ltte-is-by-no-means-a-defeat-of-thetamil-people/14-9307 [Accessed: 10 ${ }^{\text {th }}$ August 2014].

Keerawella, G. (2013) Post-War Sri Lanka: Is Peace a Hostage of the Military Victory? Dilemmas of Reconciliation, Ethnic Cohesion and Peace-Building, ICES Research Paper No. 13, Colombo: ICES [Online] Available from: http://www.ices.lk/ wp-content/uploads/2013/11/Gamini-Keerawella-book.pdf [Accessed: $25^{\text {th }}$ January 2016].

Keerawella, G. (2014) Postcolonial Statebuilding in Sri Lanka: Approaches, Attempts and Challenges, In Pinnawala, S. (ed) Identity Politics and State-Building in Sri Lanka: Understanding Ethno-nationalist Mobilization in a Postcolonial State in Transition, pp: 169-240, Colombo: Pathfinder Foundation and the Institute for the Study of Human Rights.

Khoo, S. (2013) Southern Theory: The Global Dynamics of Knowledge in Social Science, Policy \& Practice: A Development Education Review, 16 (Spring), pp: 150-155.

Kraxberger, B. M. (2007) Failed States: Temporary Obstacles to Democratic Diffusion or Fundamental Holes in the World Political Map?, Third World Quarterly, (28)6, pp: 1055-1071 [Online] Available from: http://www.jstor.org/stable/20454982 [Accessed: $11^{\text {th }}$ February 2014].

Lam. P. E. (1999) Singapore: Rich State, Illiberal Regime, In Morley, J. W. (ed) Driven by Growth: Political Change in the Asia-Pacific Region, pp: 255-274, New York: M. E. Sharpe.

Lam. P. E. (2015) The Politics of Confucianism and Asian values in Singapore, In Hsieh. J. (ed) Confucian Culture and Democracy, pp: 111-130, Singapore: World Scientific.

Lam. P. E. (2012) Parallel Orders in Post-Cold War East Asia: Power, Institutions, Markets and Identity, In Satoh. H. (ed) Rethinking East Asia: Order, Values and Interests, pp: 23-36, Tokyo: Konrad Adenauer Stiftung.

Lars-Erik, C. (2001) Back to Kant: Reinterpreting the Democratic Peace as a Macrohistorical Learning Process, The American Political Science Review, (95)1, pp: 15-31 [Online] Available from: http://www.jstor.org/stable/3117626 [Accessed: $13^{\text {th }}$ January 2013].

Lazar, S. \& Nuijten, M. (2013) Citizenship, the self and political agency, Critique of Anthropology, 33(1) Special issue on Citizenship, pp: 3-7 [Online] Available from: http:// coa.sagepub.com/content/33/1/3.refs [Accessed: $17^{\text {th }}$ February 2015]. 
Lederach, J. P. \& Stork, J. (1993) The Intervention in Somalia: What Should Have Happened: An Interview with John Paul Lederach, Middle East Report, 181 Radical Movements: Migrants, Workers and Refugees, pp: 38-42 [Online] Available from: http://www.jstor.org/stable/3013022 [Accessed: $6^{\text {th }}$ February 2014].

Levy, Y. \& Ellis., T. J. (2006) A Systems Approach to Conduct an Effective Literature Review in Support of Information Systems Research, Informing Science Journal, (9), pp: 181-212 [Online] Available from: http://www.inform.nu/Articles/Vo19/ V9p181-212Levy99.pdf [Accessed: 20 ${ }^{\text {th }}$ March 2017].

Lipset, S. M. (1959) Some Social Requisites of Democracy: Economic Development and Political Legitimacy, The American Political Science Review, 53 (1), pp: 69-105 [Online] Available from: http://www.jstor.org/stable/1951731 [Accessed: $11^{\text {th }}$ February 2014].

Liyanage, S. \& Sinnathamby, M. (2007) A Glimmer of Hope: A New Phase in Constitutional Reforms in Sri Lanka, Colombo: South Asia Peace Institute.

Locke, J. (1690) Treatises on Government [Online] Available from: http://www.gutenberg.org/files/7370/7370-h/7370-h.htm [Accessed: $10^{\text {th }}$ April 2014].

Loganathan, K. (1996) Sri Lanka: Lost Opportunities, Colombo: Centre for Policy Research and Analysis, University of Colombo.

Lynch, A. (2002) Woodrow Wilson and the Principle of 'National Self-Determination': A Reconsideration, Review of International Studies, 28(2), pp: 419-436 [Online] Available from: http://www.jstor.org/stable/20097800 [Accessed: 21 $1^{\text {st }}$ January 2014].

Mac Ginty, R. (2011) International Peacebuilding and Local Resistance: Hybrid Forms of Peace, New York: Palgrave Macmillan.

DOI: https://doi.org/10.1057/9780230307032

Manor, J. (1983) Sri Lanka: Explaining the Disaster. The World Today, 39 (11), pp: 450-459 [Online] Available from: http:// www.jstor.org/stable/40395451 [Accessed: $25^{\text {th }}$ January 2016].

Mehta, U. S. (1999) Liberalism and Empire: A Study in Nineteenth Century British Liberal Thought, Chicago: University of Chicago Press.

Mendeloff, D. (2004) Truth-Seeking, Truth-Telling, and Postconflict Peacebuilding: Curb the Enthusiasm?, International Studies Review, 6(3), pp: 355-380 [Online] Available from: http://www.jstor.org/stable/3699695 [Accessed: 21 ${ }^{\text {st }}$ February 2014].

Mendis, G. C. (1956) The Colebrooke-Cameron Papers: Documents on British Colonial Policy in Ceylon 1796 - 1833, Oxford:Oxford University Press.
Migdal, J. S. (2001) State in Society - Studying How States and Societies Transform and Constitute One Another, Cambridge: Cambridge University Press.

Min Kim, H. \& Rousseau, D. L. (2005) The Classical Liberals Were Half Right (or Half Wrong): New Tests of the 'Liberal Peace', Journal of Peace Research, 42(5), pp: 523-543 [Online] Available from: http://www.jstor.org/stable/30042367 [Accessed: 25 th January 2016].

Mutalib. H. (2000) Illiberal democracy and the future of opposition in Singapore, Third World Quarterly, 21(2), pp: 313342 [Online] Available from: http://www.tandfonline.com/doi/ abs/10.1080/0143659005000437 [Accessed: $1^{\text {st }}$ October 2016].

Nandy, A. (1983) The Intimate Enemy: The Loss and Recovery of Self under Colonialism, Delhi: Oxford University Press.

Nandy, A. (2014) The Intimate Enemy: The Loss and Recovery of Self under Colonialism, Delhi: Oxford University.

Obeyesekere, G. (2006) Buddhism, ethnicity, and identity: a problem in Buddhist history, In Deegalle, M. (ed) Buddhism, Conflict and Violence in Modern Sri Lanka, pp: 134-162, Oxon: Routledge.

Orjuela, C. (2008) Identity Politics of Peacebuilding: Civil Society in War-torn Sri Lanka, New Delhi: Sage [Online] Available from: https://books.google.lk/ [Accessed: 10 $0^{\text {th }}$ August 2015].

DOI: https://doi.org/10.4135/9788132100249

Orjuela, C. (2003) Building Peace in Sri Lanka: A Role for Civil Society?, Journal of Peace Research, 40(2), pp: 195-212 [Online] Available from: http://www.jstor.org/stable/3648411 [Accessed: 25 $5^{\text {th }}$ January 2016].

Oslon, K. (2008) Constructing Citizens, The Journal of Politics, 70(1), pp: 40-53 [Online] Available from: http://www.jstor.org/ stable/10.1017/S0022381607080036 [Accessed: $17^{\text {th }}$ February 2015].

Owen, J. J. (2004) The Task of Liberal Theory after September 11, Perspectives on Politics, 2(2), pp: 325-330 [Online] Available from: http://www.jstor.org/stable/3688444 [Accessed: $17^{\text {th }}$ February 2016].

Paris, R. (1997) Peacebuilding and the Limits of Liberal Internationalism, International Security, 22(2), pp: 54-89.

DOI: https://doi.org/10.1162/isec.22.2.54

Paris, R. (2011) Critiques of Liberal Peace, In Campbell. S., Chandler, D. \& Sabaratnam, M. (eds) A Liberal Peace? The Problems and Practices of Peacebuilding, London: Zed Books.

Paris, R. (2001) Human Security: Paradigm Shift or Hot Air?, International Security, 26(2), pp: 87-102 [Online] Available from: http://www.jstor.org/stable/3092123 [Accessed: $3^{\text {rd }}$ June 2013]. 
Paris, R. (2006) Bringing the Leviathan Back In: Classical versus Contemporary Studies of the Liberal Peace, International Studies Review, 8(3), pp: 425-440 [Online] Available from: http://www.jstor.org/stable/3880255 [Accessed: $3^{\text {rd }}$ June 2013].

Paris, R. (2002) International Peacebuilding and the 'Mission Civilisatrice', Review of International Studies, 28(4), pp: 637-656 [Online] Available from: http:/www.jstor.org/ stable/20097819 [Accessed: $3^{\text {rd }}$ June 2013].

Parliament of the Democratic Socialist Republic of Sri Lanka (1987) $13^{\text {th }}$ Amendment to the Constitution - Certified 14-111987 [Online] Available from: http://www.parliament.lk/en/ constitution/amendments-upto-the-seventeenth-amendment [Accessed: 26 ${ }^{\text {th }}$ December 2015].

Peacebuilding Initiative (2014) Operationalizing Peacebuilding [Online] Available from: http://www.peacebuildinginitiative. org/index 4599.html?pageId=1765 [Accessed: 24 ${ }^{\text {th }}$ February 2014].

Peltonen, H. (2014) In or out? International community membership: beliefs, behaviour, contextuality and principles, Cambridge Review of International Affairs, 27(3), pp: 475-494.

DOI: https://doi.org/10.1080/09557571.2012.684669

Perera, J. (2015) Reconciliation requires the full commitment of a SuduNelum Movement, Sunday Island, 30 ${ }^{\text {th }}$ March 2015 [Online] Available from: http://www.island.lk/index.php?page cat $=$ article-details $\&$ page $=$ article-details $\&$ code_title $=122347$ [Accessed: $9^{\text {th }}$ August 2014].

Phadnis, U. \& Ganguly, R. (2001) Ethnicity and NationBuilding in South Asia, New Delhi: Sage.

Pinnawala, S. (ed) (2014) Identity Politics and State-Building in Sri Lanka: Understanding Ethno-nationalist Mobilization in a Postcolonial State in Transition, Colombo: Pathfinder Foundation and the Institute for the Study of Human Rights.

Polat, N. (2010) Peace as War, Alternatives: Global, Local, Political, 35(4), pp: 317-345 [Online] Available from: http:// www.jstor.org/stable/41319265 [Accessed: $15^{\text {th }}$ January 2013].

PRIO (2016) Data [Online] Available from: https://www.prio. org/Data/ [Accessed: $2^{\text {nd }}$ October 2016].

Radin, A. M. (2012) The Limits of State Building: The Politics of War and Ideology of Peace, Unpublished doctoral dissertation, Massachusetts Institute of Technology, Massachusetts [Online] Available from: http://hdl.handle.net/1721.1/74462 [Accessed: $20^{\text {th }}$ August 2013].

Ratnatunga, S. (1988) Politics of Terrorism, Belconnen, A.C.T: International Fellowship for Social and Economic Development.

Rawls, J. (1971) A Theory of Justice, USA: Belknap Press.
Rawls, J. (1993) The Law of Peoples, Critical Inquiry, 20(1), pp: 36-68 [Online] Available from: http://www.jstor.org/ stable/1343947 [Accessed: $14^{\text {th }}$ March 2014].

Recchia, S. (2009) Just and Unjust Postwar Reconstruction: How Much External Interference Can Be Justified?, Ethics \& International Affairs, 23(2), pp: 165-187 [Online] Available from:http://www.stefanorecchia.net/1/137/resources/ publication_1032_1.pdf [Accessed: $3^{\text {rd }}$ February 2015].

Richmond, O. P. \& Franks, J. (2009) (edition 2011) Liberal Peace Transitions: Between Statebuilding and Peacebuilding, Edinburgh: Edinburgh University Press.

Richmond, O. P. \& Mac Ginty, R. (2014) Where now for the critique of liberal peace?, Cooperation and Conflict, 50(2), pp: 171-189 [Online] Available from: http://cac.sagepub.com/ content/early/2014/08/20/0010836714545691 [Accessed: $10^{\text {th }}$ September 2014].

Richmond, O. P. (2008) Peace in International Relations, UK: Routledge.

DOI: https://doi.org/10.4324/9780203927335

Richmond, O. P. (2015) The Impact of Socio-Economic Inequality on Peacebuilding and Statebuilding, Civil Wars, 16(4), pp: 449-467 [Online] Available from: Retrieved February 3, 2015, from http://www.tandfonline.com/doi/abs/10 $.1080 / 13698249.2014 .985876 \#$.VNCkuiy_R4E [Accessed: $3^{\text {rd }}$ February 2015].

Richmond, O. P. (2009) A Post-Liberal Peace: Eirenism and the Everyday, Review of International Studies, 35(3), pp: 557-580 [Online] Available from: http://www.jstor.org/stable/20542804 [Accessed: $15^{\text {th }}$ January 2015].

Richmond, O. P. (2007) Critical Research Agendas for Peace: The Missing Link in the Study of International Relations, Alternatives: Global, Local, Political, 32(2), pp: 247-274 [Online] Available from: http://www.jstor.org/stable/40645212 [Accessed: $3^{\text {rd }}$ June 2013].

Richmond, O. P. (2006) The problem of peace: understanding the 'liberal peace, Conflict, Security and Development, 6(3), pp: 291-314.

DOI: https://doi.org/10.1080/14678800600933480

Roberts, D. (2011) Beyond the metropolis? Popular peace and post-conflict peacebuilding, Review of International Studies, 37(5), pp: 2535-2556.

DOI: https://doi.org/10.1017/S0260210511000234

Rosato, S. (2003) The Flawed Logic of Democratic Peace Theory, The American Political Science Review, 97(3), pp: 585-602 [Online] Available from: http://www.jstor.org/ stable/3593025 [Accessed: $3^{\text {rd }}$ February 2015].

RSIS (2016) Global Pathfinder Database, Singapore: Nanyan Technological University. 
Russell, B. (1946) (edition 2004) History of Western Philosophy, London and New York: Routledge.

Russell, J. (1982) Communal Politics under the Donoughmore Constitution 1931-1947, Dehiwela: Tisara Prakasahakayo.

Russett, B. (1997) An Agenda for Peace - 1995 by Boutros Boutros-Ghali;An Agenda for Development 1995 by Boutros Boutros-Ghali; An Agenda for Democratization by Boutros Boutros-Ghali, The American Political Science Review, 91(2), pp: 494-496 [Online] Available from: http://www.jstor.org/ stable/2952431 [Accessed: $20^{\text {th }}$ January 2013].

Sabaratnam, M. (2011) The Liberal Peace? An Intellectual History of International Conflict Management, 1990-2010, In Campbell S., Chandler, D. \& Sabaratnam, M. (eds) A Liberal Peace? The Problems and Practices of Peacebuilding, pp:1330, UK: Zed Books.

Sahadevan, P. (2013) Ethnic Peacemaking in Sri Lanka, In Ganguly, R.. (ed) Autonomy and Ethnic Conflict in South and South-East Asia, pp: 46-87, Oxon: Routledge [Online] Available from: https://books.google.lk [Accessed: $25^{\text {th }}$ January 2016].

Samaraweera, V. (1972) Governor Sir Robert Wilmot Horton and the Reforms of 1833 in Ceylon, The Historical Journal, 15 (2), pp: 209-228 [Online] Available from: http://www.jstor.org/ stable/2638119 [Accessed: $10^{\text {th }}$ July 2014].

Sarvananthan, M. (2007) In Pursuit of a Mythical State of Tamil Eelam: A Rejoinder to Kristian Stokke, Third World Quarterly, 28 (6), pp: 1185-1195.

DOI: https://doi.org/10.1080/01436590701507628

Seneviratne, H. L. (1999) The Work of Kings: The New Buddhism in Sri Lanka, Chicago: University of Chicago Press.

Shinoda, H. \& Uesugi, Y. (eds) (2005) Conflict and Human Security: A Search for New Approaches of Peacebuilding, Japan: Kokusaishoin.

Shinoda, H. (1998) Conflicting Notions of National and Constitutional Sovereignty in the Discourses of Political Theory and International Relations: a Genealogical Perspective, Doctoral Thesis, UK: University of London.

Shinoda, H. (2001) Shyuken, jinken, soshite rikkennshyugi no genkaiten (Sovereignty: Human Rights and the Critical Point of Constitutionalism: A Historical and Theoretical Examination of the Right to Resistance and the Right to Intervention), The Annals of the Japanese Political Science Association, pp: 157169.

Shinoda, H. (2000) The Transformation of the Concept of State Sovereignty: Its Implications in the Theory of International Relations, International Politics, 124, pp: 89-107.

Shinoda, H. (2003) Peace-building and the Rule of Law: Theoretical and Functional Analyses of International Peace Operations, Japan: Sobunsha.
Singh, P. M. \& Kukreja, V. (2014) Federalism in South Asia, New Delhi: Routledge [Online] Available from: from https:// books.google.lk/ [Accessed: $25^{\text {th }}$ January 2016].

Stokke, K. \& Uyangoda, J. (eds) (2011) Liberal Peace in Question: Politics of State and Market Reform in Sri Lanka, UK: Anthem Press.

Stokke, K. (2007) War by Other Means: The LTTE's Strategy of Institutionalising Power Sharing in the Context of Transition from War to Peace: A Response to Muttukrishna Sarvananthan, Third World Quarterly, 28(6), pp: 1197-1201 [Online] Available from: http://www.jstor.org/stable/20454990 [Accessed: 25 ${ }^{\text {th }}$ January 2016].

Stokke, K. (2011) Liberal Peace in Question: The Sri Lankan Case, In Stokke, K. \& Uyangoda, J. (eds) Liberal Peace in Question: Politics of State and Market Reform in Sri Lanka, pp: 1-33, UK: Anthem Press.

Talpahewa, C. (2015) Peaceful Intervention in Intra-State Conflicts: Norwegian Intervention in the Sri Lankan Conflict, England and USA: Ashgate.

Tambiah, S. J. (1992) Buddhism Betrayed?, Chicago: The University of Chicago Press.

Thirangama, S. (2013) Claiming the State: Postwar Reconciliation in Sri Lanka, Humanity: An International Journal of Human Rights, Humanitarianism, and Development, 4(1), pp: 93-116.

DOI: https://doi.org/10.1353/hum.2013.0011

Tiruchelvam, N. (1989) Constitutional Reform: Principal Themes, In Amaratunga, C. (ed) Ideas for Constitutional Reform, pp: 27-33, Dehiwala: The Council for Liberal Democracy.

Tiruchelvam, N. (2000) Devolution and the Elusive Quest for Peace in Sri Lanka, In de Silva, K. M. \& Peiris, G. H. (eds) Pursuit of Peace in Sri Lanka: Past Failures and Future Prospects, pp: 183-202, Kandy: International Centre for Ethnic Studies.

Tom, P. (2011) The Liberal Peace and Post-conflict Peacebuilding in Africa: Sierra Leone, Unpublished doctoral thesis, Scotland: University of St. Andrews [Online] Available from: http://hdl.handle.net/10023/2469 [Accessed: $20^{\text {th }}$ August 2013].

Tuckness, A. (2002) Rethinking the Intolerant Locke, American Journal of Political Science, 46(2), pp: 288-298.

DOI: https://doi.org/10.2307/3088377

United Nations (1992) An Agenda for Peace, Preventive Diplomacy, Peacemaking and Peace-keeping: Report of the Secretary General [Online] Available from: http://www.undocuments.net/a47-277.htm [Accessed: $6^{\text {th }}$ February 2014].

United Nations (2014) List of Peace Keeping Operations 1948 -2013 [Online] Available from: http://www.un.org/en/ 
peacekeeping/documents/operationslist.pdf $\quad\left[\right.$ Accessed: $11^{\text {th }}$ February 2014].

University of Gothenburg (2016) Data Bases by Subject [Online] Available from: http://www.ub.gu.se/sok/db/amnen. xml [Accessed: $2^{\text {nd }}$ October 2016].

Uyangoda, J. (2008) Sri Lanka's Conflict at the Crossroads, Economic and Political Weekly, 43(26/27), pp: 8-9.

Uyangoda, J. (2011) Travails of State Reform in the Context of Protracted Civil War in Sri Lanka, In Stokke, K. \& Uyangoda, J. (eds) Liberal Peace in Question: Politics of State and Market Reform in Sri Lanka, pp: 35-61, UK: Anthem Press.

Uyangoda, J. (2015) The LTTE and Tamil Insurgencies in Sri Lanka: Political/cultural Grievance, Unsuccessful Negotiations and Organisational Evolution, In Chima, J. S. (ed) Ethnic Subnationalist Insurgencies in South Asia: Identities, Interests and Challenges to State Authority, pp: 101-123, Oxon: Routledge.

Uyangoda, J. (2007) Ethnic Conflict in Sri Lanka: Changing Dynamics, Washington: East West Center.

V-Dem (2016) Varieties of Democracy, Sweden \& USA: University of Gothenburg and University of Notra Dame.

Venugopal, R. (2011) The Politics of Market Reform in the Time of Ethnic Conflict: Sri Lanka in the Jayawardene Era, In Stokke, K. \& Uyangoda, J. (eds) Liberal Peace in Question: Politics of State and Market Reform in Sri Lanka, pp: 77 -102, UK: Anthem Press.

Verite Research (2013) Devolution of Land Powers: A Guide for Decision Makers [Online] Available from: http://www. veriteresearch.org/research-spreport-archives.cfm [Accessed: $26^{\text {th }}$ December 2015].

Viner, J. (1960) The Intellectual History of Laissez Faire, Journal of Law and Economics, 3, pp: 45-69 [Online] Available from: http://www.jstor.org/stable/724811 [Accessed: 15 ${ }^{\text {th }}$ May 2014].

Wehr, P. \& Lederach, J. P. (1991) Mediating Conflict in Central America, Journal of Peace Research, 28(1) Special Issue on
International Mediation, pp: 85-98 [Online] Available from: http://www.jstor.org/stable/424196 [Accessed: 5 ${ }^{\text {th }}$ February 2014].

Welikala, A. (2015) Constitutional Reform: A Liberal Wishlist, Groundviews, 24 $4^{\text {th }}$ March 2015 [Online] Available from: http:// groundviews.org/2015/03/24/constitutional-reform-a-liberalwish-list/ [Accessed: 26 $6^{\text {th }}$ March 2015].

Wickramasinghe, N. (2008) Sri Lanka in 2007: Military Successes, but at Humanitarian and Economic Costs, Asian Survey, 48(1), pp: 191-197 [Online] Available from: http:// www.jstor.org/stable/10.1525/as.2008.48.1.191 [Accessed: $5^{\text {th }}$ February 2016].

Wickramasinghe, N. (2009) Sri Lanka in 2008: Waging War for Peace, Asian Survey, 49(1), pp: 59-65 [Online] Available from: http://www.jstor.org/stable/10.1525/as.2009.49.1.59 [Accessed: $25^{\text {th }}$ January 2016].

Wickramasinghe, N. (2006) Sri Lanka in the Modern Age: A History of Contested Identities, Colombo: Vijitha Yapa.

Wickremaratne, A. (1995) Buddhism and Ethnicity in Sri Lanka, Kandy: International Centre for Ethnic Studies.

Wickremeratne, A. (1999) Buddhist Nationalism in Sri Lanka: Perceptions, Change and Reality, In Peiris, G. \& Samarasinghe, de A. S. W. R. (eds) History and Politics: Millennium Perspectives, Essays in Honour of K. M. de Silva, Colombo: Law and Society Trust.

Wriggins, H. (1960) Ceylon: Dilemmas of a New Nation, New Jersey: Princeton University Press.

DOI: https://doi.org/10.1515/9781400876907

Yilmaz, M. E. (2005) UN Peacekeeping In The Post-Cold War Era, International Journal on World Peace, 22(2), pp: 13-28 [Online] Available from: http://www.jstor.org/stable/20753484 [Accessed: $11^{\text {th }}$ February 2014].

Zakaria, F. (1997) The Rise of Illiberal Democracy, Foreign Affairs, 76(6), pp: 22-43.

DOI: https://doi.org/10.2307/20048274 